\title{
Checklist of the ichthyofauna of Mamirauá Sustainable Development Reserve, Middle Solimões, Amazonas, Brazil: high richness in a large protected area of Western- Central Amazonia
}

\author{
Alexandre Pucci Hercos $^{1,2 *}$ (D) ,Jonas Alves de Oliveira ${ }^{1}$, Jomara Cavalcante de Oliveira ${ }^{1,3}$, \\ Elizabeth Kathleen de Queiroz Rodrigues ${ }^{1}{ }^{(D)}$, Rita Louro Barbosa ${ }^{I}$ \& Helder Lima de Queiroz ${ }^{1}$ \\ ${ }^{1}$ Instituto de Desenvolvimento Sustentável Mamirauá, Laboratório de Ecologia e Biologia de Peixes, Estrada \\ do Bexiga 2584, Fonte Boa, 69553-225, Tefé, AM, Brasil. \\ ${ }^{2}$ Rede Ciência Cidadã para a Amazônia, Miraflores, Lima, Peru. \\ ${ }^{3}$ Secretaria de Estado de Educação e Qualidade de Ensino do Amazonas, Rua Waldomiro Lustoza 250, Japiim \\ II, 69076-830, Manaus, AM, Brasil. \\ *Corresponding author: alexandre.hercos@mamiraua.org.br
}

HERCOS, A.P., OLIVEIRA, J.A., OLIVEIRA, J.C., RODRIGUES, E.K.Q., BARBOSA, R.L., QUEIROZ, H.L. Checklist of the ichthyofauna of Mamirauá Sustainable Development Reserve, Middle Solimões, Amazonas, Brazil: high richness in a large protected area of Western-Central Amazonia. Biota Neotropica 21(4): e20211207. https://doi.org/10.1590/1676-0611-BN-2021-1207

\begin{abstract}
The present study reviews the records of occurrences of fish species found in the Mamirauá Sustainable Development Reserve (MSDR). The reserve is located in a large section of the middle Solimões River basin, in its interflow with Japurá River. For the elaboration of the list of fish species occurring in Mamirauá Reserve, we used a database of different studies on fish communities carried out in the area over the last three decades, in addition to the material deposited in the ichthyological collections of three scientific institutions, the National Institute for Amazon Research - INPA, the Mamirauá Sustainable Development Institute - IDSM and the Science and Technology Museum of the Catholic University of Rio Grande do Sul - PUCRS. The ichthyofauna of the MSDR is composed of 541 species, encompassing 45 families and 15 orders. These correspond to $20 \%$ of all valid species known for the entire Amazonia so far. As observed in other studies in the Neotropical Region, the more represented orders were Siluriformes (209 species) and Characiformes (185 species), followed by the Gymnotiformes ( 78 species). The results presented here demonstrate a considerable increase $(86 \%)$ in the knowledge about the fish diversity found in Mamirauá Reserve, in relation to its first list of fish species, published in the 90's. This increase reflects not only the growth in number of studies on fish diversity in the area, with new surveys, but also the continuous taxonomic work on the collections, and descriptions of twenty-eight new species, with one hundred and ten type series. Further surveys are expected to take place in the Northwestern, more isolated areas of the Reserve, and will allow the identification of new occurrences, and may even unveil new fish species yet to be described to Science.. Keywords: Amazon; Checklist; Distribution; First record; Neotropical; Taxonomy.

\section{Lista de verificação da ictiofauna da Reserva de Desenvolvimento Sustentável Mamirauá, Médio Solimões, Amazonas, Brasil: alto endemismo e riqueza em uma grande área protegida da Amazônia Centro-Ocidental}

\footnotetext{
Resumo: Este estudo apresenta uma revisão dos registros de ocorrências das espécies de peixes encontradas na Reserva de Desenvolvimento Sustentável Mamirauá (RDSM), ampla área localizada na bacia do Médio Solimões, em seu interflúvio com o Rio Japurá. Para a elaboração da lista de peixes que ocorrem na Reserva Mamirauá foram utilizados os bancos de dados de diferentes estudos sobre comunidades de peixes realizados na área ao longo das últimas décadas, além de informações referentes ao material tombado nas coleções ictiológicas de três instituições científicas, o Instituto Nacional de Pesquisas da Amazônia- INPA,o Instituto de Desenvolvimento Sustentável Mamirauá - IDSM e o Museu de Ciências e Tecnologia da Pontifícia Universidade Católica do Rio Grande do Sul - PUCRS. A ictiofauna da RDSM é composta por 541 espécies, incluindo 45 famílias e 15 ordens. Estes valores correspondem a cerca de $20 \%$ de todas espécies válidas conhecidas para toda a Amazônia até o momento. Assim como em outros estudos na região Neotropical as ordens que apresentaram as maiores riquezas
} 
HERCOS, A.P., et al.

foram siluriformes (209 espécies) e Characiformes (185 espécies), seguidas de Gymnotiformes (78 espécies). Os resultados apresentados neste trabalho demonstram um aumento considerável (86\%) no conhecimento sobre a diversidade de peixes encontrados na Reserva Mamirauá, em relação à primeira lista de peixes da RDSM, publicada na década de 1990. Este aumento reflete não apenas o crescimento no número de estudos sobre a diversidade de peixes na área, com a ocorrência de novos levantamentos, como também a intensificação dos trabalhos taxonômicos de classificação e descrição de vinte oito novas espécies com cento e dez séries tipos. Novos levantamentos deverão ocorrer nas áreas mais isoladas da Reserva, na sua porção noroeste. Estas atividades permitirão a identificação de novas ocorrências, e podem até revelar espécies novas a serem descritas..

Palavras-chave: Amazônia; Lista de verificação; Distribuição; Primeiro registro; Neotropical; Taxonomia.

\section{Introduction}

At the end of the XX century, an attempt to inventory the fish fauna of the Mamirauá Reserve was made, and produced a first list of 291 species (Crampton 1999). This first effort was limited by the lack of human and financial resources and did not encompassed a representative portion of the reserve. Seemingly, the problems that led to a limited list of fish species for the Mamiraua area are the same observed for the entire Amazon basin. The current knowledge on the Amazonian fish diversity is far from adequate, and the estimates on the number of existing fish species varies greatly (Malabarba et al., 1998; Carvalho et al. 2009; Albert et al. 2011; van der Sleen \& Albert 2017; Dagosta \& De Pina, 2019; Oberdorff et al., 2019). But it is widely accepted that there are approximately 2700 already described fish species living in the Amazon basin (Dagosta \& De Pina, 2019). Nevertheless, a strikingly high number of fish species are being described for the Amazon every year (Valsecchi et al., 2017). Unfortunately, a relevant portion of the currently known fish fauna, like in other important megadiverse freshwater ecosystems of the World, is now threatened (Darwall et al, 2016; Arthington et al. 2016; IBAMA, 2018). Although some of the areas of the Central Amazonia and its floodplains have been intensively surveyed during the last half century (Correa et al., 2008; Freitas et al., 2014; Siqueira-Souza et al., 2016), some areas remain virtually unknown, or very poorly known, demonstrating the importance of inventory studies in the region. There is very few information available about the fish diversity of the middle Solimões region, a vast and biologically important part of the Western Brazilian Amazonia.

For many centuries the floodplain areas of the Amazon, annually inundated by white sediment-rich waters, have been visited and studied. Most of the material collected in these expeditions was sent to foreign institutions, mainly in Europe (Filho, 2009). The majority of the large cities and small towns in the Amazon are located in the várzea ecosystem, and almost all the commercial fisheries in the Amazon is carried out in várzea water bodies. The Amazonian varzea is a particular type of wetland, a seasonal floodplain forest inundated by whitewater rivers, with an intricate mosaic of waterbodies and annually flooded shores (Junk et al., 2011; Junk et al., 2014). Probably this is why we have the existing information about its fish fauna (Santos et al., 1991; Goulding et al. 1996; Saint-Paul et al., 2000; Zuanon et al., 2008). Records are, however, focused on the large-bodied species, most of commercial value, and a very few information is available about occurrence and distribution of the fish fauna in most parts of the Amazonian várzea. This information is usually originated in species lists from very restricted areas, tend to be taxonomically unreliable and not supported by voucher specimens deposited in the main scientific fish collections. Despite these limitations, it is generally recognized that the ichthyofauna found in the Solimões-Amazonas várzea is placed among the more diverse of the Amazon, especially at the Western parts of the Central Brazilian Amazon, upstream from Manaus, the capital city of Amazonas State. This várzea ecosystem holds at least 647 fish species, including areas from the borders with Peru and Colombia, and the mouth, in the Atlantic coast (Zuanon et al., 2008).

Fish surveys and other similar studies in the Middle Solimões region were intensified in the early 1990's through an intense research program implemented to support the regulation of the management for the newly created Mamirauá Sustainable Development Reserve-RDSM. The RDSM was the first protected area of this category implemented in Brazil. One of the main characteristics of this type of protected area, is the participatory management of natural resources by the local populations, combined with the scientific research to support their activities (Queiroz 2005). In this way, a large inventory was made for the Mamirauá Reserve area and its adjacent rivers, generating a first list of fish species (Crampton 1999). The vast majority of the material collected at that time was deposited in large national collections such as INPA, and also the Science and Technology Museum of Pontifical Catholic University of Rio Grande do Sul (PUCRS). Part of this material collected at Mamirauá Reserve was used to build a small reference collection at Mamirauá Institute, located in the town of Tefé, Amazonas State.

Subsequently, with the consolidation of the Mamirauá Sustainable Development Institute (IDSM), several other inventories were carried out in the region, generating new lists of fish species for the RDSM, and representing a considerable increase in the knowledge about the richness of the fish fauna of that protected area. The previous reference collection was greatly improved with new deposits from this reserve and other protected areas, and also from different parts of the Western Brazilian Amazonia, which became the current IDSM ichthyological collection. However, this recently generated information on the RDSM was never compiled in a single checklist. Therefore, the goal of the present paper, is to provide an updated list of the fish fauna that occur in the Mamirauá Sustainable Development Reserve.

\section{Material and Methods}

\section{Study area}

The fish collections were all conducted during field expeditions to the Mamirauá Sustainable Development Reserve (RDSM), in the Brazilian Central Amazon floodplain (Figure 1). Mamirauá is a wetland site of international importance listed under the UN Ramsar Convention, and the largest protected area of flooded forests in Brazil. The whole reserve's area $(1,124,000 \mathrm{ha})$ if formed exclusively by the lowland floodplains of the Solimões and Japurá rivers, a complex mosaic of flooded forests interspaced by different types of water bodies; lakes, "canos" (channels), rivers and "paranãs" (river connections), each of them with particular physical and biological features, but connected at least once a year, since the entire reserve is completely flooded for 3 to 6 months annually (Henderson, 1999). The mosaic of forests (Wittmann et al. 2006) and water bodies, lakes and channels, at Mamirauá is typical of the várzea environment (Figure 2). 


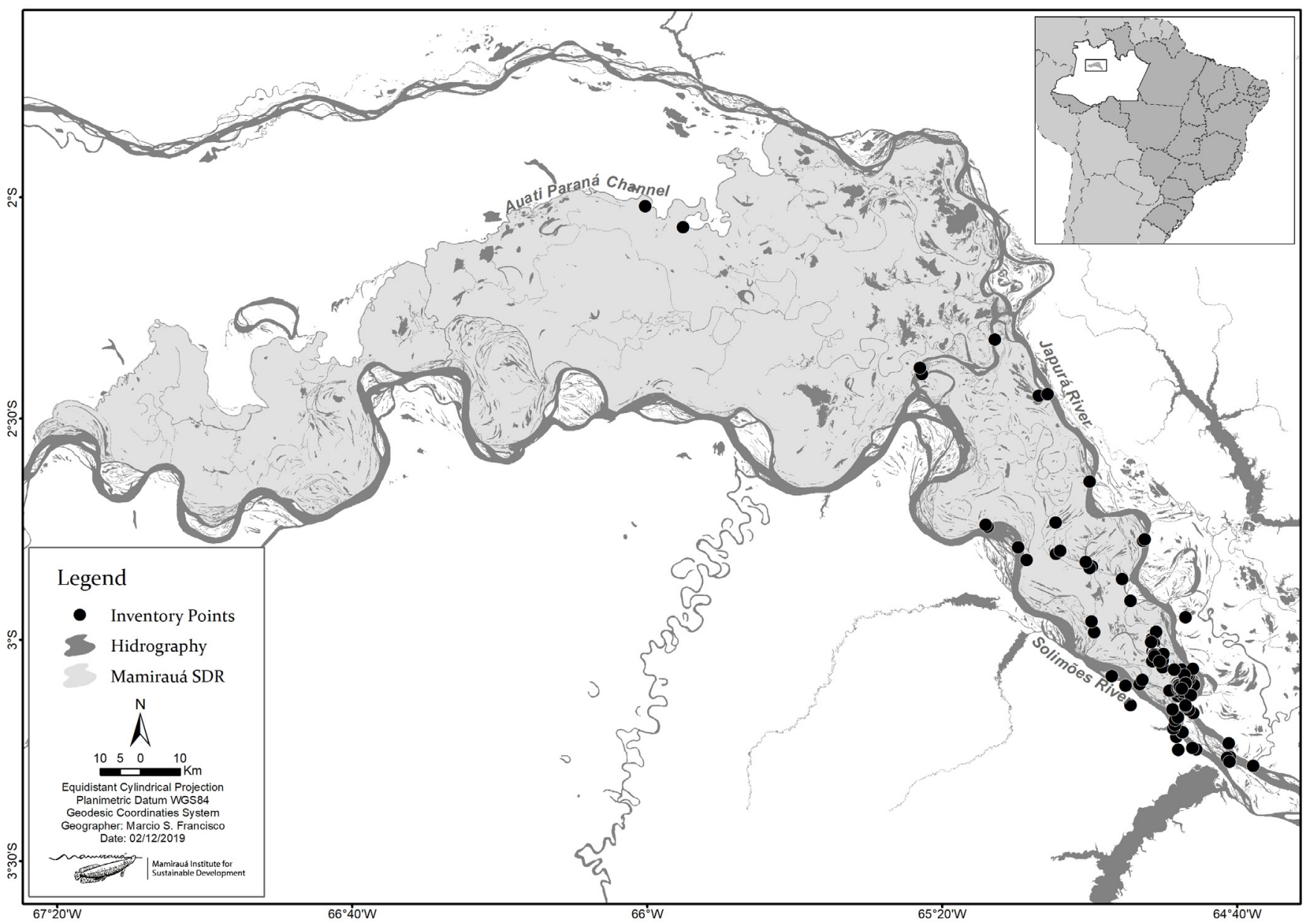

Figure 1. Map showing the Mamirauá Sustainable Development Reserve, Amazonas State, Brazil, with the geographical distribution of the points of distribution of fish sampling sites (black dots), and the main water bodies in the region (rivers, lakes and channels).
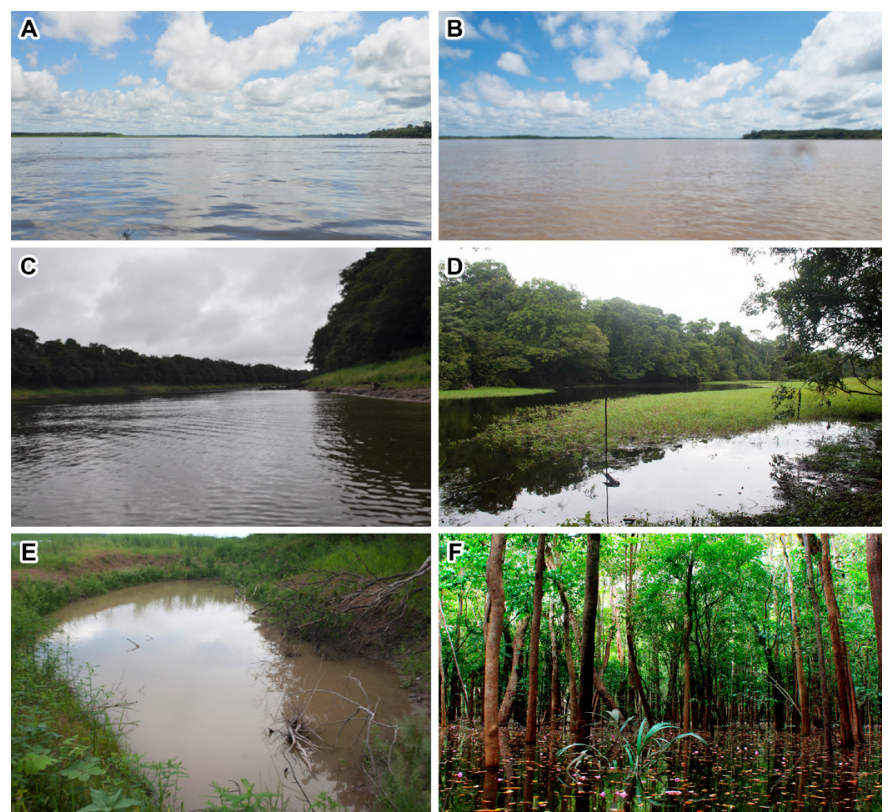

Figure 2. Examples of permanent and temporary aquatic environments sampled during the fish collections carried out at the Mamirauá Reserve: a) Japurá River; b) Solimões River; c) Mamirauá lake channel; d) Taracuazinho lake; e) Taxizal flood pool; f) Igapó (flooded forest) in Mamiraua system lake.
During a complete hydrological cycle, the water level in Mamirauá varies by more than $10 \mathrm{~m}$ (Ramalho et al. 2009), alternating wet and dry periods in a typical annual flood pulse (Junk et al., 1989). Four seasons can be identified, based on water level (Gaston \& He, 2011). These are (i) high water season, from May until mid-July; (ii) falling water season, from mid-July to September; (iii) low water season, in the months of September, October and November; and (iv) rising water season, from December to April. These water bodies support a large fish fauna (Henderson \& Crampton 1997), with diverse communities in each of the major aquatic habitats present (Henderson \& Hamilton 1995).

The floodplain area in the confluence of Japurá and Solimões Rivers, where Mamirauá is located, is characterized by high atmospheric temperatures with average annual ranging from $28^{\circ} \mathrm{C}$ to $30^{\circ} \mathrm{C}$, with maximum monthly ranging from $33^{\circ} \mathrm{C}$ to $35^{\circ} \mathrm{C}$ and minimum monthly ranging from $20^{\circ} \mathrm{C}$ to $22^{\circ} \mathrm{C}$. The highest precipitations are concentrated between December and May (Ramalho et al., 2009) when it can reach $300 \mathrm{~mm}$ per month during the wettest years and the annual precipitation in the reserve is in average $3000 \mathrm{~mm}$. The Japurá and Solimões Rivers consists of large white water rivers, carrying sediments from the erosion of the Andes, and forming large inundated habitats. Solimões River is one of the largest Amazonian rivers (discharge $53.3 \times 10^{3} \mathrm{~m}^{3} / \mathrm{second}$ ) and the main channel of the Amazon Basin, until it gets the discharge of blackwaters from the Negro River and creates the mighty Amazon River. Japurá River, on the other hand, 
although smaller (discharge 14,5 $\times 10^{3} \mathrm{~m}^{3} / \mathrm{second}$ ) is the Brazilian name for the Caquetá River, from Colombia. Successive erosion and deposition processes along the geological history of this floodplain created a complex mosaic of permanent and temporary waterbodies. The annual variation of water level responds for the various degrees of connectivity between those different waterbodies and the two main rivers. There are five main aquatic environments types in the Mamirauá Reserve relevant to the present work, since they were systematically surveyed over the years: the main rivers, lakes, canos and paranãs, flooded florest and the temporary pools formed inside the forest, when the water level recedes. The paranãs are channels connecting the main rivers, while the canos are channels that transport water from the rivers and from main channels to lower order aquatic environments within the floodplain, like smaller channels or lakes. Since canos are very shallow, some of them may dry completely during the low water periods. The lakes, on the other hand, may vary in shapes and sizes, and usually retain water during the entire hydrologic cycle. Therefore, lakes may retain a loose connection to the main channel during low water phase. During the high water period, all water bodies are connected and a direct communication is established among them all (Table 1).

\section{Data collection}

To prepare this checklist, a database was built with the information from different studies carried out mainly in the Southern, Eastern and Southeastern parts of the area (see black dots in Figure 1) over the last decades (Crampton, 1999; Chaves 2006; Santos 2007; Reis 2007). Whenever necessary, the collected material was revised in the fish collection of the IDSM. Additionally, we searched for all material collected at the RDSM in other important ichthyological collections in Brazil: Museum of Science and Technology (MCP) of the Pontifical Catholic University of Rio Grande do Sul, Museum of Zoology of the University of São Paulo (MZUSP), University of Campinas (ZUEC) and National Institute for Amazonian Research (INPA), available on SpeciesLink (www.specieslink.org.br). After the list was compiled, possible names and synonyms, and their occurrence, were confronted with information available in the Eschmeyer's Catalog of Fishes (Fricke et al.2020). To avoid possible synonymies between species cataloged by the many studies in the area, we applied the precautionary principle and remove all risks of double entries.

\section{Results}

Until the present, the ichthyofauna of the Mamirauá Sustainable Development Reserve is composed of 541 species, including 45 families and 15 orders (Table 2). These figures correspond to about $20 \%$ of all species valid for the Amazon (Dagosta and De Pinna 2019), and represent a $86 \%$ increase in relation to the first list produced for the RDSM, published in the end of the last century (Crampton, 1999). As detected in other studies and fish fauna surveys in Neotropical sites, the most represented orders were Siluriformes, with 209 species, and Characiformes, with 185 species (Beltrão and Soares 2018; Beltrão et al. 2019; Dagosta and De Pinna 2019). Together they represent more than $70 \%$ of the fish species richness at Mamirauá Reserve. Next in importance comes the Gymnotiformes, with 78 species. The gymnotids are remarkably diverse at the Mamirauá Reserve, where several new species have been described during the last two decades (Albert \& Crampton 2001; Crampton et al. 2004; Crampton et al. 2005) (Figure 3f). At least, three new gymnotid species were recently discovered, two Apteronotids and one Hypopomids, and are under description. In the fourth place, the Cichliformes, with 40 species, is another species-rich order present. At Mamirauá we included in the checklist Apistogrammoides pucallpaensis Meinken, 1965, which had its first record for Brazil published recently (Oliveira et al. 2019) (Figure 3d).

The species richness at the family level also follows the general pattern found in the Neotropics. The five richest families are Characidae, with 61 species, Loricariidae with 55 species, Cichlidae with 37 species, Apteronotidae with 33 species and Auchenipteridae with 25 species. These numbers correspond to $39 \%$ of the total species richness at Mamirauá. Remarkably, family Characidae alone holds $11 \%$ of the total richness, demonstrating the diversity of this fish family at the protected area.

The richest aquatic environment present was the floodplain lakes (369 spp.), followed by the "canos" and paranás (301 spp.), and the rivers (261 spp.). In all aquatic environments Characiformes was the dominant order, followed by Siluriformes and Cichliformes. Such richness distribution among orders is expected for the Neotropical fish fauna, being reported from several prior studies (Queiroz et al., 2013; Sleen and Albert, 2018; Beltrão et al., 2019; Dagosta and De Pinna, 2019) (figure 4).

From the names included in the first fish species list published for Mamirauá Reserve (Crampton, 1999), we removed those identified only at the genus level, since they are not present in the material deposited in any known biological collection. They are Saccoderma sp.1, Pimelodus sp.1, Pseudostegophilus sp.1, Hoplosternum sp.1, Plagioscion sp.1 and "Petalodoras sp.1". We also removed Knodus

Table 1. Physical and chemical parameters of water quality for the water bodies at Mamirauá Reserve based on Henderson (1999), Affonso et al. (2011 and 2015) and Pedro et al. (2013).

\begin{tabular}{|c|c|c|c|c|c|c|c|c|c|}
\hline \multirow[b]{2}{*}{ Parameters } & \multicolumn{2}{|c|}{ Solimões River } & \multicolumn{2}{|c|}{ Japurá River } & \multicolumn{2}{|c|}{ Várzea Lakes } & \multicolumn{2}{|c|}{ Várzea Canos and Paranãs } & \multirow{2}{*}{$\begin{array}{c}\text { Temp. Pools } \\
\text { Low } \\
\text { Water }\end{array}$} \\
\hline & $\begin{array}{c}\text { High } \\
\text { Water }\end{array}$ & $\begin{array}{c}\text { Low } \\
\text { Water }\end{array}$ & $\begin{array}{c}\text { High } \\
\text { Water }\end{array}$ & $\begin{array}{c}\text { Low } \\
\text { Water }\end{array}$ & $\begin{array}{c}\text { High } \\
\text { Water }\end{array}$ & $\begin{array}{c}\text { Low } \\
\text { Water }\end{array}$ & $\begin{array}{c}\text { High } \\
\text { Water }\end{array}$ & $\begin{array}{c}\text { Low } \\
\text { Water }\end{array}$ & \\
\hline $\mathrm{pH}$ & 6.9 & 6.8 & 6.36 & 6.60 & 6.85 & 7.01 & 6.84 & 7.29 & 6.95 \\
\hline Eletr. Conduc. $(\mu \mathrm{S} . \mathrm{cm}-1)$ & 87.7 & 200.6 & 77.3 & 131.0 & 115.29 & 85.21 & 110.53 & 231.02 & 155.29 \\
\hline Temperature $\left({ }^{\circ} \mathrm{C}\right)$ & 27.1 & 31.3 & 27.8 & 30.9 & 27.27 & 31.52 & 26.62 & 31.32 & 28.14 \\
\hline
\end{tabular}



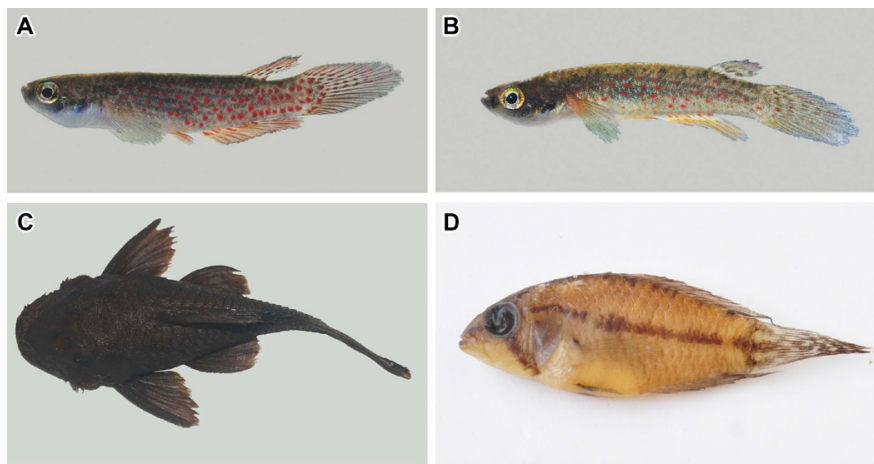

D

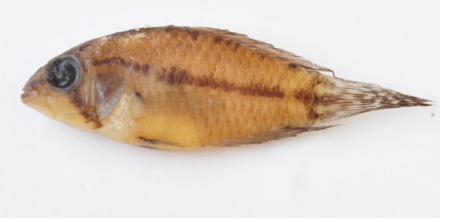

E

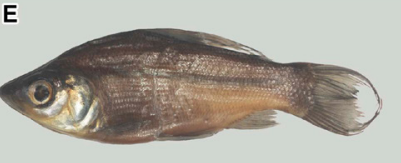

F
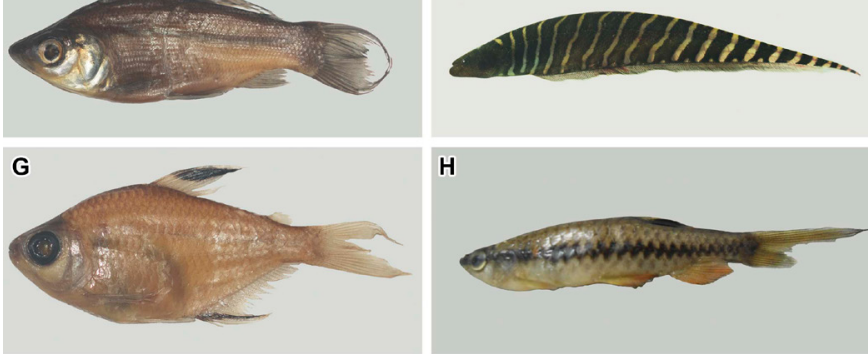

H
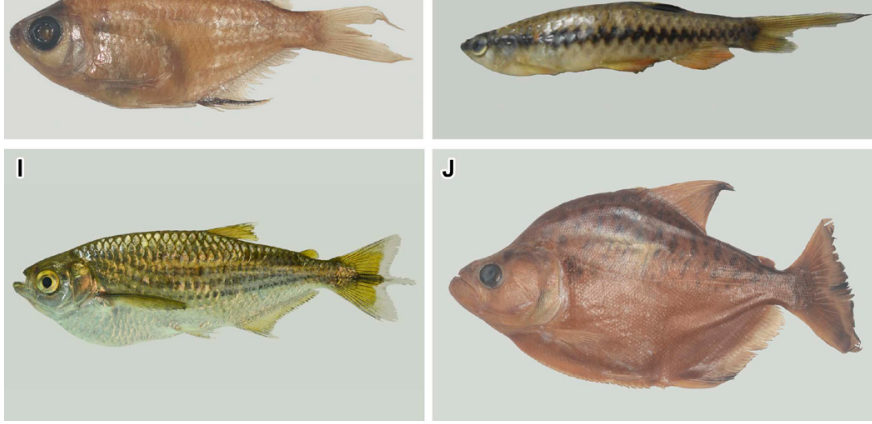

Figure 3. Representative individuals of some species collected at Mamiraua Reserve: a) Anablepsoides "mamiraua" sp.n ô; b) Anablepsoides "mamiraua" sp.n + ; c) Ancistrus cf. hoplogenys; d) Apistogrammoides pucallpaensis; e) Curimatopsis microlepis; f) Gymnotus mamiraua; g) Moenkhausia hemigrammoides; h) Pyrrhulina zigzag; i) Triportheus angulatus; j) Serrasalmus sp. n.

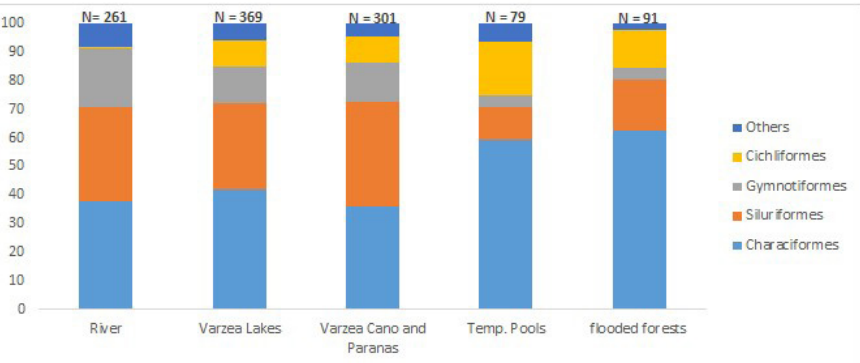

Figure 4. Ranking of richness by Orders and habitat of fish species found in the Mamirauá Sustainable Development Reserve (MSDR), $\mathrm{N}=$ Number of species.

sp.1 and Tetragonopterus sp.1, both included in a scientific report (M. Catarino, unpublished), informed as collected and identified only at the genus level. We found no correspondence with any material deposited in the collections consulted. Additionally, in the present version of the fish species list, we removed three names identified at the species level, mentioned in inventories and studies carried out at Mamirauá Reserve, but not deposited in any biological collection. They are Microglanis carlae Vera Alcaraz, da Graça \& Shibatta, 2008, Nannostomus harrisoni (Eigenmann, 1909), Crenicichla cametana Steindachner, 1911 and Lycengraulis grossidens (Spix \& Agassiz 1829). The decision to remove these four entries from the list was based on the consideration that Microglanis carlae has its distribution restricted to the Paraguay River basin; Nannostomus harrisoni has its distribution restricted to the Demerara river basin in Guyana, and that Crenicichla cametana, occurs only in the Xingu and Tocantins-Araguaia river basins (Dagosta and De Pinna 2019). Lycengraulis grossidens is a marine/estuarine species, with not confirmed records for freshwater habitats, and freshwater specimens identified. Consequently, it is more likely that these were misidentifications made by those responsible for the reports of the inventories consulted.

The miniature Crenuchidae Elachocharax pulcher Myers, 1927 (sensu Weitzman and Vari 1988; Toledo-Piza et al. 2014), and the hemiodontid Hemiodus atranalis (Fowler, 1940) were added to this list because they were recently captured at the Mamirauá Reserve, and we also included in our list three more species that just had their first records for the Solimões river basin, Curimatopsis microlepis, Moenkhausia hemigrammoides Géry, 1965 and Pyrrhulina zigzag Zarske \& Géry, 1997 (Figures 3e; 3g; 3h).

Serrasalmus cf. spilopleura and Mesonauta insignis have their geographic distribution falling far from the Mamirauá Reserve area, and their occurrence can be questioned (Dagosta and De Pinna 2019; Kullander and Silfvergrip, 1991). A careful review of the identification of these species should be conducted in the near future.

Fifty-seven taxa in the list were not identified at the species level, and thus have an uncertain identification at this level. They were included in the list because there are deposited material in scientific collections to voucher for their names. Forty of them were identified only at the genus level, such as Potamotrygon sp.1, Microcharacidium sp.1, Microschemobrycon sp.1 and Ancistrus sp.1"mancha dorsal". Sixteen species were pre-determined with "cf.", such as Metynnis cf. maculatus, Jupiaba cf. zonata and Ancistrus cf. hoplogenys (Figure 3f). Eight species are new and are now under the process of description, listed here as Characidium sp. n., Serrasalmus sp. n., Paravandellia sp. n., Plectrochilus sp. n., Brachyhypopomus sp. n., Adontosternarchus sp. n., Sternarchella sp. n. and Anablepsoides"mamiraua"sp. n. (Figures 3a; 3b; 3c).

\section{Discussion}

The fish fauna found at the Mamirauá Reserve is typical of the Amazonian várzea ecosystem. Like other parts of the várzea (Zuanon et al. 2008), the more represented or richest families detected at RDSM fish fauna were Characidae, Loricariidae and Cichlidae. Species found at várzea lakes at the vicinity of the Solimões river (Saint-Paul et al., 2000; Freitas et al., 2014; Siqueira-Souza et al., 2016) are very similar to those found at lakes in Mamirauá. Similarly, the species found in floating meadows mattresses at the Eastern Peruvian Amazon (Correa et al., 2008) are also similar to those found in the floating meadows at Mamirauá. However, in all those previous accounts, species richness was not as high as the one found at Mamirauá Reserve and its aquatic environments. The study area is located in a part of the várzea considered exceptionally species-rich, and holding a set of important endemic species (Zuanon et al., 2008).

By any account, the Amazon basin has a superlative number of fish species. Available estimates vary greatly, but most of them suggest a number that may reach 3,500 species (Malabarba et al., 1998; Junk et al. 2007; Carvalho et al. 2009; Albert et al. 2011; van der Sleen \& Albert 2017; 
HERCOS, A.P., et al.

Dagosta \& De Pina, 2019). However, some other authors suggest a significant upward trend, and that this number may reach up to 5,000 species in the next 70 years, if we maintain the current rate of description of new species (Ota et al. 2015). These values suggest that the Amazon fish fauna may represent about $15 \%$ of all freshwater fish species described in the world at the present (Oberdorff et al. 2019). The Congo River basin, in Africa, is considered the second most diverse river basin in the world, with less than half the number of fish species registered for the Amazon River basin (Snoeks et al. 2011).

Species richness in a particular area is the result of several processes operating at multiple spatial and temporal scales (Peláez \& Pavanelli 2018), comprising numerous evolutionary lineages, resulting from the interaction of geological factors associated with vicariant and dispersion agents (Lundberg, 1998; Dagosta and de Pinna 2017). The distribution of fish species in the Amazonian sub-basins and adjacent drainage systems is complex, and amounts to numerous distribution overlaps and superlative degrees of biogeographic congruence (Dagosta and De Pinna 2017). The diversity patterns of this mega-fauna and the processes that generate these patterns are still only partially known (Dagosta and De Pinna 2019). However, recent studies suggest that the richness pattern of the Amazonian ichthyofauna is supported mainly by three factors: area, climate and energy availability (Oberdorff et al. 2019). The pattern shown here for Mamirauá fish species diversity is consistent with the recent predictions, but the pattern of fish endemism at Mamirauá is much higher than expected (Oberdorff et al., 2019).

The total number of species listed for the Mamirauá Reserve is considerably higher than in other studies, with the species richness at Middle Solimões basin reaching figures higher than those from other Amazonian sub-basins, such as the Tapajós River basin (with 529 species), the Xingu River basin (with 502 species), even though the study area of the MiddleSolimões corresponds to a small proportion of those two sub-basins. In addition, its known species richness reaches about $63 \%$ to $85 \%$ of the total species registered for the main channel of the Amazon River, depending on the source adopted (Zuanon et al., 2008; Dagosta and De Pinna 2019). This high value we found is probably the result of two combined factors. The first would be the high sampling effort applied during the last decades to the study area (Figure 5). The ichthyofauna of many Amazonian regions remain under-sampled, some of them are still nearly unknown to science, with no biological collection performed so far. Consequently, the differences in species richness found may simply reflect the difference in collection efforts (Queiroz et al. 2013). The two sub-basins under the greatest sampling effort are the same with the highest richness, the Negro River, with 1165 registered species (Beltrão et al. 2019), and the Madeira River, with 1062 species. Besides those two we have, of course, the main river channel, the Solimões-Amazonas, with 922 species recorded (Dagosta and De Pinna 2019).

The other explaining factor that may be responsible for the high species richness recorded would be the location of the Mamirauá Reserve and its environmental diversity. Located in the interflow of two great rivers, Solimões and Japurá, and in a large floodplain area, Mamirauá Reserve has a complex mosaic of bodies of water that are repeatedly connected and isolated, at least once a year. This type of ecosystem and the dynamics of its permanent or temporary aquatic environments provide several habitats and microhabitats that are distinct, and therefore can support a very high species richness (Figure 4). In this part of the Amazonian floodplains the water level rises annually around $11 \mathrm{~m}$ (Ramalho et al., 2009), invading a mosaic of equally diverse array of forest types, and connecting and isolating all the local water bodies, sometimes for many consecutive months, probably with important implications for the richness of fish species in the area (Junk, et al. 1989; Arantes et al., 2017. In each part of the hydrological cycle, the aquatic environments present at the várzea can show a striking variation in water quality parameters (see Table 2). Besides that, Mamirauá Reserve lays at the confluence of the Japurá River, and the mouths of Tefé, Jutaí and Juruá Rivers are also very close, just few kilometers away. This high proximity to many other river basins and their fish faunas, with distinct levels of dissimilarity among them, could be another source of diversity and species richness. The distribution of the fish species in the Amazon sub-basins and adjacent drainage systems is complex, and amounts to numerous distributional

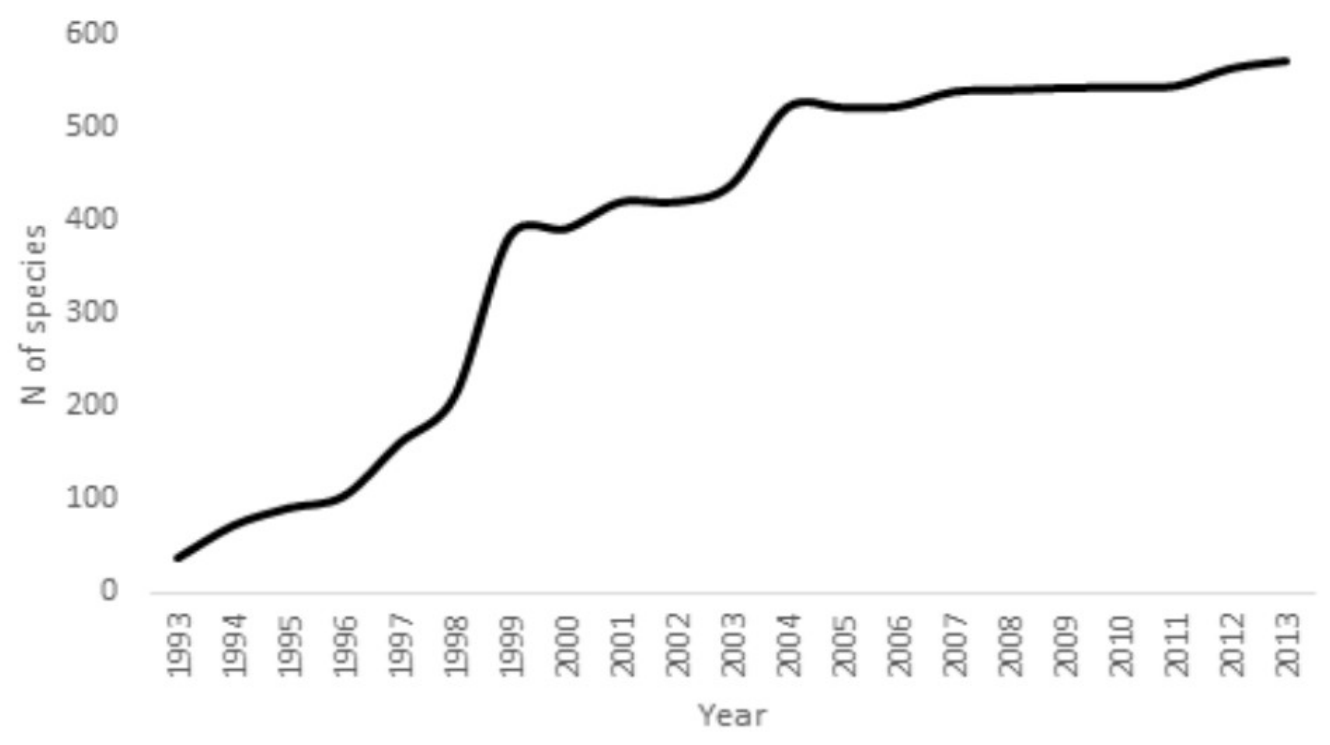

Figure 5. Species accumulation curve per year in the list of fish species recorded for Mamirauá Sustainable Development Reserve. 
overlaps and superlative degrees of biogeographic congruence (Dagosta and de Pinna 2017). In the same way the high species richness of the Solimões River near Manaus can also be explained by its close proximity to the mouth of the Negro River (Zuanon et al., 2008).

None of the species recorded for the study area is listed as threatened of extinction, according with the International Union for Conservation of Nature (IUCN) and IBAMA (2018). Since the 2000's, several new species have been described for the area, almost all of them belonging to the Gymnotiformes, demonstrating a high species richness of this particular order at the Mamirauá Reserve, as in other várzea areas with habitats of similar diversity and structural complexity. This is probably due to the high number of taxonomic studies on this particular group of fish at Mamirauá (Albert \& Crampton 2001; Crampton et al. 2004; Crampton et al. 2005; Correa et al. 2006; Albert and Crampton 2006; de Santana \& Crampton 2007; de Santana \& Crampton 2010; de Santana \& Vari 2010; Lundberg et al. 2013; Sullivan et al. 2013; Carvalho \& Albert 2015; Crampton et al. 2016; Evans et al. 2017).

It is expected that, as new undersampled areas are explored and surveyed, especially in the Northwestern part of Mamirauá Reserve, another significant increase in the fish species list will be achieved. As can be said for the whole Amazon, improvements in the sampling effort, together with continued taxonomic revision of the collected material, will result in the increase in the number of records, of new occurrences, and even in the description of new fish species for the study area. Recent studies on the Neotropical fish fauna have led to a significant improvement on the knowledge on fish diversity in the Amazon as never before (Sleen and Albert 2018; Dagosta and De Pinna 2019; Oberdorff et al. 2019), and we expect that this trend will be maintained or improved for the next decades.

\section{Acknowledgments}

The authors wish to thank Dr Henrique Lazzarotto, Dr Michel Catarino, MSc Rose Chaves, MSc Marília Santos, MSc Liana Reis and Marcela Sobanski, for carrying out fish surveys and processing the samples. Thanks to Dr Renildo Ribeiro de Oliveira for providing information on the fish lots deposited at INPA, to the Research Group on Geospatial Analysis, Environment and the Amazon Territory of the Mamirauá Institute for preparing the map, to Diego Matheus de Mello Mendes for images of fish species. We also want to thank the Mamirauá Sustainable Development Institute for support in logistics and infrastructure. Thanks to the National Council for Scientific and Technological Development $\mathrm{CNPq}$ for the research grants (processes 300694/2016-4, 312542/2016-0, $300019 / 2017-3,300503 / 2019-9,305539 / 2019-1$ and 301024/2020-0) and for the scientific initiation scholarship of some assistants in the laboratory. Thanks to Wildlife Conservation Society and Gordon and Betty Moore Foundation for their financial support.

\section{Author Contributions}

Alexandre Pucci Hercos: elaboration of study's concept and design; data collection, analysis and preparation of manuscript.

Jonas Alves de Oliveira: elaboration of study's concept and design; data collection and analysis.

Jomara Cavalcante de Oliveira: elaboration of study's concept and design; data collection, analysis and preparation of manuscript.

Elizabeth Kathleen de Queiroz Rodrigues: elaboration of study's concept and design; data collection, analysis and preparation of manuscript.

Rita Louro Barbosa: data collection, analysis and preparation of manuscript. Helder Lima de Queiroz: elaboration of study's concept and design; data collection, analysis and preparation of manuscript.

Table 2. List of fish species found at the Mamirauá Sustainable Development Reserve, during inventories, surveys and research on fish autoecology, biology and fish community ecology. * Paratype; **Holotype; ***Neotype. IDSM = Instituto de Desenvolvimento Sustentável Mamirauá; MCP = Museu de Ciências e Tecnologia da Pontifícia Universidade Católica do Rio Grande do Sul; INPA = Instituto Nacional de Pesquisa da Amazônia; MZUSP = Museu de Zoologia da Universidade de São Paulo; ZUEC = Museu de Zoologia da Universidade Estadual de Campinas.

\begin{tabular}{lc}
\hline ESPÉCIE & FONTE \\
\hline MYLIOBATIFORMES: Potamotrygonidae & \\
\hline Potamotrygon constellata (Vaillant, 1880) & IDSM3017 \\
Potamotrygon henlei (Castelnau, 1855) & MCP32907 \\
Potamotrygon histrix (Müller \& Henle, 1839) & IDSM3018 \\
Potamotrygon motoro (Müller \& Henle, 1841) & IDSM3019 \\
Potamotrygon sp.1 & MCP32891
\end{tabular}

OSTEOGLOSSIFORMES: Osteoglossidae

Osteoglossum bicirrhosum (Cuvier, 1829) IDSM254; IDSM1106; INPA-ICT18698

OSTEOGLOSSIFORMES: Arapaimidae

$\begin{array}{ll}\text { Arapaima gigas (Schinz, 1822) } & \text { IDSM3020 }\end{array}$

CLUPEIFORMES: Engraulidae

Anchoviella alleni (Myers, 1940)

INPA-ICT18808; MCP29620; MCP29621

Anchoviella guianensis (Eigenmann, 1912)

IDSM1918

Jurengraulis juruensis (Boulenger, 1898)

IDSM23; INPA-ICT19407; INPA-ICT18782

Lycengraulis batesii (Günther, 1868)

IDSM24; IDSM41; MCP29902; MCP29903

Lycengraulis cf. figueiredoi

MCP30002

CLUPEIFORMES: Pristigasteridae 
HERCOS, A.P., et al.

...continuation

Ilisha amazonica (Miranda Ribeiro, 1920)

IDSM1099; INPA-ICT19280

Pellona castelnaeana (Valenciennes, 1847)

IDSM53

Pellona flavipinnis (Valenciennes, 1837)

Pristigaster cayana Cuvier, 1829

IDSM43; IDSM1091; IDSM1836; MCP29649; MCP29650

Pristigaster whiteheadi Menezes, de \& Pinna, 2000

INPA-ICT18718

\section{CHARACIFORMES: Crenuchidae}

Characidium aff. Zebra

Crenuchus spilurus Günther, 1863

IDSM1932

Characidium sp. $n$.

IDSM3021

Microcharacidium sp. 1

IDSM3016

MCP29347; MCP29348; MCP29349; MCP29350; MCP29436; MCP29437; MCP29438; MCP29439

\section{CHARACIFORMES: Erythrinidae}

Hoplerythrinus unitaeniatus (Spix \& Agassiz, 1829)

Hoplias malabaricus (Bloch, 1794)
Erythrinus erythrinus (Bloch \& Schneider, 1801)

IDSM116; IDSM167; IDSM328; INPA-ICT19242; MCP29924; MCP29925; MCP29926; МCP29927

IDSM117; INPA-ICT19246

IDSM196; IDSM214; IDSM238; IDSM285; IDSM1135; IDSM2653; MCP32755; MCP32756; MCP32757; MCP32759; MCP32760

CHARACIFORMES: Cynodontidae

Cynodon gibbus Spix \& Agassiz, 1829

Hydrolycus scomberoides (Cuvier, 1819)

Rhaphiodon vulpinus Spix \& Agassiz, 1829

IDSM1104; IDSM1966; IDSM35; IDSM137

MCP30586

\section{CHARACIFORMES: Serrasalmidae}

Colossoma macropomum (Cuvier, 1818)

Metynnis altidorsalis Ahl, 1923

Metynnis hypsauchen (Müller \& Troschel, 1844)

Metynnis luna Cope, 1878

Metynnis maculatus (Kner, 1858)

Myloplus asterias (Müller \& Troschel, 1844)

Myloplus rhomboidalis (Cuvier, 1818)

Myloplus rubripinnis (Müller \& Troschel, 1844)

Myloplus schomburgkii (Jardine \& Schomburgk, 1841)

Myloplus torquatus (Kner, 1858)

Mylossoma aureum (Spix \& Agassiz, 1829)

Mylossoma albiscopum (Cope 1872)

Piaractus brachypomus (Cuvier, 1818)

Pristobrycon calmoni (Steindachner, 1908)

Pristobrycon striolatus (Steindachner, 1908)
IDSM2996

IDSM1394; IDSM1395; IDSM1396; IDSM1397; IDSM1398; IDSM1399; IDSM1400; IDSM1401; IDSM1402; IDSM1403; IDSM1473

In the process of cataloging

IDSM1467; IDSM1468; IDSM1470; IDSM1471; IDSM1472; IDSM1517; IDSM1727; IDSM1521; MCP31637

IDSM1739

IDSM1453; IDSM1454; IDSM1455; IDSM1456; IDSM1457; IDSM1459; IDSM1460; IDSM1461; IDSM1462; IDSM1463; IDSM1464; IDSM1465; IDSM1466; IDSM1516

In the process of cataloging

IDSM1732; IDSM1452; MCP31638

In the process of cataloging

IDSM1093

IDSM233; IDSM1014; IDSM1518; IDSM1519; IDSM1689; IDSM1505; IDSM1514; IDSM1695; IDSM1696; IDSM1703; IDSM1704; IDSM1733; IDSM1737; IDSM1740; IDSM1741; IDSM1742; MCP31679; MCP31681

IDSM194; IDSM232; IDSM283; IDSM1035; IDSM1504; IDSM1506; IDSM1507; IDSM1508; IDSM1509; IDSM1510; IDSM1511; IDSM1513; IDSM1530; IDSM1645; IDSM1690; IDSM1692; IDSM1693; IDSM1694; IDSM1697; IDSM1698; IDSM1699; IDSM1700; IDSM1701; IDSM1702; IDSM1705; IDSM1706; IDSM1707; IDSM1708; IDSM1709; IDSM1710; IDSM1711; IDSM1712; IDSM1714; IDSM1715; IDSM1726; IDSM1728; IDSM1729; IDSM1730; IDSM1731; IDSM1734; IDSM1735; IDSM1736; IDSM1738; IDSM1743; MCP31654; MCP31656 IDSM205; IDSM1120; IDSM1691

MCP29976; MCP29977; MCP29978; MCP29979; MCP29980; MCP29981; MCP29982; МCP29983

IDSM1412; IDSM1421; IDSM1422; IDSM1423; IDSM1424; IDSM1425 
...continuation

Pristobrycon sp. 1

Pygocentrus nattereri Kner, 1858

Serrasalmus cf. altipinis

Serrasalmus eigenmanni Norman, 1929

Serrasalmus elongatus Kner, 1858

Serrasalmus maculatus Kner, 1858

Serrasalmus medinai Ramírez, 1965

Serrasalmus rhombeus (Linnaeus, 1766)

Serrasalmus serrulatus (Valenciennes, 1850)

Serrasalmus sp. $n$.

Serrasalmus sp. 1

Serrasalmus aff. spilopleura Kner, 1858
MCP33149

IDSM127; IDSM234; IDSM1114; IDSM1426; IDSM1427; IDSM1428; IDSM1429; IDSM1430; IDSM1431; IDSM1432; IDSM1433; IDSM1434; IDSM1435; IDSM1436; IDSM1437; IDSM1438; IDSM1439; IDSM1440; IDSM1441; IDSM1442; IDSM1443; IDSM1444; IDSM1445; IDSM1446; IDSM1448; IDSM1449; IDSM1450; IDSM1451; IDSM1520; IDSM1522; IDSM1523; IDSM1524; IDSM1526; IDSM1527; IDSM1528; MCP32747; MCP32748; MCP32749

MCP33213; MCP33214;

IDSM1416; IDSM1417; IDSM1418; IDSM1419; IDSM1420; IDSM163; IDSM1414

IDSM136; IDSM235; IDSM1406; IDSM1515; IDSM2308; MCP31652; MCP32900; MCP32901; MCP32902; MCP32904

IDSM1407; IDSM1408; IDSM1411; IDSM1883

IDSM2302; IDSM256; IDSM1713

IDSM261; IDSM333; IDSM113; IDSM1251; IDSM1405; IDSM1409; IDSM1481; IDSM1482; IDSM1483; IDSM1484; IDSM1485; IDSM1486; IDSM1487; IDSM1489; IDSM1490; IDSM1492; IDSM1494; IDSM1495; IDSM1496; IDSM1497; IDSM1498; IDSM1499; IDSM1500; IDSM1501; IDSM1502; IDSM1503; IDSM1512; IDSM1716; IDSM1717; IDSM2299; IDSM2300; IDSM2301; IDSM2304; IDSM2305; IDSM2307; IDSM2309; IDSM2310; IDSM1744; IDSM255; MCP32905 MCP33038

IDSM1474; IDSM1475; IDSM1476; IDSM1477; IDSM1478; IDSM1479; IDSM1480

MCP31677; MCP31678; MCP32753; МCP32754; МCP32894; МCP32895; MCP32897; MCP32909; MCP33198; MCP33200; МCP33201; MCP33202; MCP33203; MCP33205; MCP33206; MCP33207; МCP33209

CHARACIFORMES: Hemiodontidae

Anodus elongatus Agassiz, 1829

IDSM2202; MCP30042

Hemiodus gracilis Günther, 1864

Hemiodus argenteus Pellegrin, 1908

Hemiodus atranalis (Fowler, 1940)

In the process of cataloging

In the process of cataloging

IDSM3063

MCP31710

IDSM3064

IDSM3015

Hemiodus unimaculatus (Bloch, 1794)

CHARACIFORMES: Anostomidae

Abramites hypselonotus (Günther, 1868)

Anostomoides atrianalis Pellegrin, 1909

Laemolyta proxima (Garman, 1890)

Laemolyta taeniata (Kner, 1859)

Leporinus agassizi Steindachner, 1876

Leporinus cf. niceforoi

Leporinus fasciatus (Bloch, 1794)

Leporinus friderici (Bloch, 1794)

\author{
IDSM1046; IDSM1652; IDSM1796; IDSM1828 \\ IDSM3022 \\ INPA-ICT18852; INPA-ICT18853; IDSM91 \\ IDSM1105; IDSM1955; IDSM1964; IDSM1970 \\ IDSM151; IDSM334; IDSM1033; INPA-ICT19293 \\ IDSM1971; IDSM1973; INPA-ICT18805 \\ IDSM1971; IDSM1973; INPA-ICT18805
}

IDSM29; IDSM152; IDSM226; IDSM1878; INPA-ICT19347; INPAICT19346; INPA-ICT19341; INPA-ICT19340; INPA-ICT19339;

INPA-ICT19338; INPA-ICT19335; INPA-ICT19333; INPA-ICT19332;

INPA-ICT19330; INPA-ICT19329; INPA-ICT19327; INPA-ICT19326; INPA-ICT19325; INPA-ICT19324; INPA-ICT19319; MCP31647 MCP32810; MCP32811; MCP32812; MCP32813; MCP32814; MCP32815

continue... 
HERCOS, A.P., et al.

...continuation

Leporinus jamesi Garman, 1929

Megaleporinus trifasciatus Steindachner, 1876

Pseudanos gracilis (Kner, 1858)

Pseudanos trimaculatus (Kner, 1858)

Rhytiodus argenteofuscus Kner, 1858

Rhytiodus microlepis Kner, 1858

Schizodon fasciatus Spix \& Agassiz, 1829
MCP33034; MCP33121

IDSM149; IDSM153; IDSM1884; IDSM2103; INPA-ICT19351; INPAICT19350; INPA-ICT19349; INPA-ICT19348; MCP29754; MCP29755; MCP29756

IDSM2997

IDSM1084; INPA-ICT19309; INPA-ICT19308

IDSM259; IDSM1073; INPA-ICT19306; MCP32935

IDSM125; IDSM154; IDSM165; IDSM1054; INPA-ICT19289; INPAICT19288; MCP29923

IDSM1638; IDSM1972; IDSM155; IDSM198; IDSM1638; INPA-ICT19546; INPA-ICT18712; MCP29992; MCP29993; MCP29994; MCP29995

CHARACIFORMES: Chilodontidae

Caenotropus labyrinthicus (Kner, 1858)

IDSM30; MCP33026; MCP33027

Caenotropus sp. 1

IDSM1143; IDSM2118

IDSM3065

\section{CHARACIFORMES: Curimatidae}

Curimata incompta Vari, 1984

IDSM2204

Curimata knerii Steindachner, 1876

MCP30627

Curimata vittata (Kner, 1858)

Curimatella alburna (Müller \& Troschel, 1844)

Curimatella dorsalis (Eigenmann \& Eigenmann, 1889)

Curimatella meyeri (Steindachner, 1882)

Curimatopsis evelynae Géry, 1964

IDSM105; IDSM1121

IDSM146; IDSM330; IDSM1077; IDSM1891; IDSM1949; INPA-ICT19264

In the process of cataloging

MCP29607; МCP30621

IDSM1865

IDSM1079

IDSM2998

IDSM1859

IDSM103; IDSM108; INPA-ICT19262

MCP33043

IDSM2999

MCP29543; MCP29545; IDSM3000

IDSM27; IDSM1900; MCP29381

Potamorhina altamazonica (Cope, 1878)

Potamorhina latior (Spix \& Agassiz, 1829)

Psectrogaster amazonica Eigenmann \& Eigenmann, 1889

Psectrogaster essequibensis (Günther, 1864)

Psectrogaster rutiloides (Kner, 1858)

Steindachnerina bimaculata (Steindachner, 1876)

Steindachnerina hypostoma (Boulenger, 1887)

Steindachnerina leucisca (Günther, 1868)

IDSM26; IDSM1103; IDSM1818; IDSM1899; MCP32936

IDSM225; IDSM3001

IDSM1946

IDSM135; IDSM1806; IDSM1846; MCP29795; MCP29796

MCP33140

IDSM1851; IDSM1847; MCP29931

IDSM28; IDSM1061; IDSM1947; IDSM1948; MCP33141 MCP33142; MCP33143; MCP33144

\section{CHARACIFORMES: Prochilodontidae}

Prochilodus nigricans Spix \& Agassiz, 1829

IDSM99; IDSM223; IDSM1137; IDSM1803; MCP29711; MZUSP27925.0

Semaprochilodus insignis (Jardine, 1841)

IDSM1804; IDSM1108; IDSM204

Semaprochilodus taeniurus (Valenciennes, 1821)

IDSM224

\section{CHARACIFORMES: Lebiasinidae}

Copeina guttata (Steindachner, 1876)

IDSM3002

Copella gr. nattereri

IDSM3038

Copella callolepis (Regan, 1912)

IDSM1138; IDSM1906; IDSM2657 
...continuation

Nannostomus eques Steindachner, 1876

IDSM1908; IDSM1957

Nannostomus unifasciatus Steindachner, 1876

IDSM1907; IDSM1956

Nannostomus trifasciatus Steindachner, 1876

In the process of cataloging

Pyrrhulina australis Eigenmann \& Kennedy 1903

IDSM2658

Pyrrhulina brevis Steindachner, 1876

IDSM222

Pyrrhulina filamentosa Valenciennes, 1847

In the process of cataloging

Pyrrhulina semifasciata Steindachner, 1876

IDSM183; IDSM207; IDSM1122; IDSM1905; IDSM2654

Pyrrhulina vittata Regan, 1912

IDSM3003

Pyrrhulina zigzag Zarske \& Géry, 1997

IDSM2607; IDSM2671; IDSM2672; IDSM2673

\section{CHARACIFORMES: Ctenoluciidae}

Boulengerella maculata (Valenciennes, 1850)

IDSM3066

Boulengerella cuvieri (Spix \& Agassiz, 1829)

MCP32767

\section{CHARACIFORMES: Chalceidae}

Chalceus erythrurus (Cope, 1870)

IDSM1083; IDSM1653; IDSM1890; INPA-ICT18619; INPA-ICT19286

\section{CHARACIFORMES: Triportheidae}

Agoniates anchovia Eigenmann, 1914

Triportheus albus Cope, 1872

Triportheus angulatus (Spix \& Agassiz, 1829)

Triportheus auritus (Valenciennes, 1864)

DSM31; IDSM1038; IDSM1549; IDSM1759; IDSM1936; IDSM2137;

INPA-ICT19531; INPA-ICT19529; MCP29799; MCP29801; MCP29804

IDSM1102; IDSM1931; MCP29940; MCP29941; MCP299942

IDSM1755; IDSM1789; IDSM1053; INPA-ICT19303; INPA-ICT18767; MCP29943***; MCP29944; MCP29945; MCP29947

IDSM1100; IDSM1756

\section{CHARACIFORMES: Gasteropelecidae}

Carnegiella marthae Myers, 1927

Carnegiella strigata (Günther, 1864)

Gasteropelecus sternicla (Linnaeus, 1758)

Thoracocharax stellatus (Kner, 1858)

\section{IDSM2622; IDSM2660; IDSM1118; IDSM1825}

IDSM2627

\section{IDSM237; IDSM997; INPA-ICT18821}

IDSM55; IDSM1060; IDSM1101; IDSM1758; IDSM1791; IDSM1830; IDSM1838; IDSM1839; IDSM1852; IDSM1860; IDSM1937; IDSM2136; IDSM2625; INPA-ICT18816; MCP29568; MCP29569

\section{CHARACIFORMES: Bryconidae}

Brycon amazonicus (Spix \& Agassiz, 1829)

INPA-ICT19118; INPA-ICT19108; INPA-ICT19107; MCP29758; IDSM0111; IDSM228; MZUSP27924.0

Brycon falcatus Müller \& Troschel, 1844

IDSM176

Brycon melanopterus (Cope, 1872) In the process of cataloging

\section{CHARACIFORMES: Iguanodectidae}

Bryconops melanurus (Bloch, 1794)

Iguanodectes geisleri Géry, 1970

In the process of cataloging

IDSM1911; IDSM2133

IDSM3005

Iguanodectes purusii (Steindachner, 1908)

Iguanodectes spilurus (Günther, 1864)

IDSM1126; MCP30630

Piabucus dentatus (Koelreuter, 1763)

IDSM3006

\section{CHARACIFORMES: Acestrorhynchidae}

Acestrorhynchus abbreviatus (Cope, 1878)

Acestrorhynchus falcatus (Bloch, 1794)

Acestrorhynchus falcirostris (Cuvier, 1819)

Acestrorhynchus microlepis (Schomburgk, 1841)

Acestrorhynchus nasutus Eigenmann, 1912

Gnathocharax steindachneri Fowler, 1913

\section{CHARACIFORMES: Characidae}

Aphyocharax gr. dentatus
IDSM1968; INPA-ICT19179; INPA-ICT19178; INPA-ICT19177; MCP29973
IDSM213
IDSM114; INPA-ICT18833; MCP29558; MCP29559
IDSM115; MCP30588; MCP30590
IDSM3007
IDSM3008 
HERCOS, A.P., et al.

...continuation

Aphyocharax pusillus Günther, 1868

Astyanax sp.1

Astyanax bimaculatus (Linnaeus, 1758)

Boehlkea fredcochui Géry, 1966

Brachychalcinus copei (Steindachner, 1882)

Charax condei (Géry \& Knöppel, 1976)

Charax gibbosus (Linnaeus, 1758)

Charax tectifer (Cope, 1870)

Chrysobrycon sp. 1

Ctenobrycon hauxwellianus (Cope, 1870)

Ctenobrycon spilurus (Valenciennes, 1850)

Galeocharax gulo (Cope, 1870)

Gymnocorymbus thayeri Eigenmann, 1908

Hemigrammus belottii (Steindachner, 1882)

Hemigrammus analis Durbin, 1909

Hemigrammus haraldi Géry 1961

Hemigrammus hyanuary Durbin, 1918

Hemigrammus levis Durbin, 1908

Hemigrammus luelingi Géry, 1964

Hemigrammus ocellifer (Steindachner, 1882)

Hemigrammus rodwayi Durbin, 1909

Hemigrammus unilineatus (Gill, 1858)

Hemigrammus aff. worderwinkleri

Hyphessobrycon bentosi Durbin, 1908

Hyphessobrycon copelandi Durbin, 1908

Jupiaba cf. zonata

Microschemobrycon sp. 1

Moenkhausia ceros Eigenmann, 1908

Moenkhausia chrysargyrea (Günther, 1864)

Moenkhausia collettii (Steindachner, 1882)

Moenkhausia collettii "alta"

Moenkhausia comma Eigenmann, 1908

Moenkhausia cotinho Eigenmann, 1908

Moenkhausia dichroura (Kner, 1858)

Moenkhausia gracilima (Eigenmann, 1908)

Moenkhausia grandisquamis (Müller \& Troschel, 1845)

Moenkhausia hemigrammoides Géry, 1965

Moenkhausia intermedia Eigenmann, 1908

Moenkhausia lata Eigenmann, 1908

Moenkhausia lepidura (Kner, 1858)

Moenkhausia megalops (Eigenmann, 1907)

Moenkhausia melogramma Eigenmann, 1908

Moenkhausia cf. naponis
IDSM44; IDSM45; IDSM1037; IDSM1130; IDSM1667; IDSM1787; IDSM1809; IDSM1933; MCP29551; MCP29552; MCP29553; MCP29580; MCP29581; MCP32769

IDSM2188; IDSM2212

IDSM3024

IDSM1141

IDSM1930; IDSM2162

IDSM3025

INPA-ICT18779

IDSM1843

IDSM2159

IDSM2171

IDSM1136; IDSM1525; IDSM1566; IDSM1781; IDSM1896; IDSM1951; IDSM2624; INPA-ICT18793

IDSM1082; IDSM1919; IDSM2186

IDSM1864; IDSM2184; IDSM2185; IDSM2606; IDSM2644

IDSM3009

IDSM1912

IDSM193; IDSM1945; IDSM2111; IDSM1858

IDSM3010

IDSM1915

IDSM2656

IDSM1617; IDSM1139; IDSM2626

IDSM1914

IDSM1124; IDSM1824; IDSM1897; IDSM2189; IDSM2623; IDSM2630

IDSM3026

IDSM3027

In the process of cataloging

IDSM150

IDSM039

IDSM2569

In the process of cataloging

IDSM1823; IDSM2655

In the process of cataloging

In the process of cataloging

IDSM1096

IDSM229; IDSM1095; IDSM1913; IDSM1765; IDSM1888; IDSM1895; IDSM1954; IDSM1969; IDSM1974; INPA-ICT18703; INPA-ICT18702

IDSM1921; IDSM1938

In the process of cataloging

IDSM1909

IDSM85; IDSM1782; IDSM1040; IDSM1885; INPA-ICT18701; INPAICT18700; INPA-ICT18699

IDSM2567

IDSM1065; IDSM1953; IDSM2092

In the process of cataloging

IDSM1075; IDSM1866; IDSM1910; IDSM2209; IDSM2659

IDSM1762; IDSM1784; IDSM1934; IDSM2101 
...continuation

Moenkhausia oligolepis (Günther, 1864)

Odontostilbe fugitiva Cope, 1870

Paragoniates alburnus Steindachner, 1876

Phenacogaster pectinatus (Cope, 1870)

Phenacogaster sp. 1

Poptella compressa (Günther, 1864)

Prionobrama filigera (Cope, 1870)

Prodontocharax alleni Böhlke, 1953

Prodontocharax melanotus Pearson, 1924

Protocheirodon pi (Vari, 1978)

Roeboides affinis (Günther, 1868)

Roeboides myersii Gill, 1870

Serrapinnus gr. gracilis

Stethaprion erythrops Cope, 1870

Stichonodon insignis (Steindachner, 1876)

Tetragonopterus argenteus Cuvier, 1816

Tetragonopterus chalceus Spix \& Agassiz, 1829

\section{GYMNOTIFORMES: Apteronotidae}

Adontosternarchus balaenops (Cope, 1878)

Adontosternarchus clarkae Mago-Leccia, Lundberg \& Baskin, 1985

Adontosternarchus sachsi (Peters, 1877)

Adontosternarchus nebulosus Lundberg \& Cox Fernandes 2007

Adontosternarchus sp. $n$.

Apteronotus albifrons (Linnaeus, 1766)

Apteronotus apurensis Fernández-Yépez, 1968

Apteronotus bonapartii (Castelnau, 1855)

Compsaraia compsa (Mago-Leccia, 1994)

Compsaria samueli Albert \& Crampton, 2009

Pariosternarchus amazonensis Albert \& Crampton, 2006
IDSM1123; INPA-ICT18721; INPA-ICT18723

IDSM2573; IDSM2574

MCP29612; MCP29850

IDSM3028

In the process of cataloging

IDSM1134; IDSM1532; IDSM1780; IDSM2196

IDSM1557

MCP29863; MCP31917

IDSM54; IDSM1760; IDSM1792; IDSM1795; IDSM1810; IDSM1849; IDSM1854; IDSM2571; IDSM2572

IDSM1808; IDSM2591

IDSM1564; IDSM1935; IDSM1920; IDSM1840; IDSM999; IDSM1845; INPAICT19543; INPA-ICT19540; INPA-ICT19539; INPA-ICT19538; MCP29988

IDSM76; IDSM86; IDSM230; IDSM231; IDSM260; IDSM1036; IDSM1805; INPA-ICT19521; INPA-ICT9520; INPA-ICT19519; INPAICT19518; INPA-ICT19517; INPA-ICT19516; INPA-ICT18736; MCP30577; MCP30578; MCP30580; MCP30581; MCP30582; MCP30583; МCP30584

IDSM998; IDSM1898

IDSM2126; IDSM2170; INPA-ICT19564; MCP29909; MCP29910 IDSM1080

IDSM75; IDSM282; IDSM1783; IDSM1802; IDSM1844; IDSM1967; IDSM2105; INPA-ICT18693; INPA-ICT18692

INPA-ICT18707
IDSM2175; IDSM2293; IDSM1820; IDSM211; IDSM1003; INPA-ICT18272; INPA-ICT18271; INPA-ICT18270; INPA-ICT18269; INPA-ICT18268; INPAICT18266; INPA-ICT11520; MCP33386; MCP33387; MCP33390; MCP39314; MCP39315; MCP39316; MCP39317; MCP39318; MCP39319; MCP39320; MCP39321; MCP39322; MCP39323; MCP39324; MCP39325; MCP39326; MCP39327; MCP39328; MCP39329

IDSM1004; IDSM1801; IDSM1799; IDSM1829; IDSM1877; IDSM2076; IDSM2639; IDSM785; IDSM289; IDSM2096; INPA-ICT18230; INPAICT18229; INPA-ICT15809; INPA-ICT9971; MCP39330; MCP39331; MCP39332; MCP39333; MCP39334; MCP39335; MCP39336; MCP39337; MCP39338; MCP39339; MCP39340; MCP39341; MCP39342

IDSM279; INPA-ICT18278; INPA-ICT15808; INPA-ICT11519; MCP39352; MCP39353; MCP39354; MCP39355

\section{INPA-ICT17311*}

MCP39302*; MCP39303*; MCP39304**; MCP39305*; MCP39306*; MCP39307*; MCP39308*; MCP39309*; MCP39310; MCP39311; MCP39312; МCP39313 IDSM828; IDSM1066; IDSM1867; INPA-ICT18179

INPA-ICT18298; INPA-ICT18256; INPA-ICT18255; INPA-ICT18254; INPAICT18156; INPA-ICT15834; INPA-ICT15811; INPA-ICT15803

IDSM744; IDSM745; IDSM775; IDSM776; IDSM994; IDSM1798; IDSM1822; IDSM1826; IDSM1868; IDSM1944; IDSM2061; IDSM2070; IDSM2174; IDSM2082; IDSM2031; IDSM2032; IDSM2033; IDSM2034; INPA-ICT09970 In the process of cataloging IDSM 276 MCP34916**; MCP34917* 
HERCOS, A.P., et al.

...continuation

Parapteronotus hasemani (Ellis, 1913)

Platyurosternarchus macrostomus (Günther, 1870)

Porotergus duende de, Santana \& Crampton, 2010

Porotergus gimbeli Ellis, 1912

Porotergus gymnotus Ellis, 1912

Sternarchella calhamazon Lundberg, Cox Fernandes, Campos, da, Paz \& Sullivan, 2013

Sternarchella duccis (Lundberg, Cox Fernandes \& Albert, 1996)

Sternarchella raptor (Lundberg, Cox Fernandes \& Albert, 1996)

Sternarchella rex Evans, Crampton \& Albert 2017

Sternarchella schotti (Steindachner, 1868)

Sternarchella terminalis (Eigenmann \& Allen, 1942)

Sternarchella sp. $n$.

Sternarchogiton nattereri (Steindachner, 1868)

Sternarchogiton porcinum Eigenmann \& Allen, 1942

Sternarchogiton $\mathrm{sp} .1$

Sternarchorhamphus muelleri (Steindachner, 1881)

Sternarchorhynchus cramptoni de, Santana \& Vari, 2010

Sternarchorhynchus curvirostris (Boulenger, 1887)

Sternarchorhynchus mormyrus (Steindachner, 1868)

Sternarchorhynchus oxyrhynchus (Müller \& Troschel, 1849)

Sternarchorhynchus sp.1

Tenebrosternarchus preto (de Santana \& Crampton, 2007)

GYMNOTIFORMES: Sternopygidae

Distocyclus conirostris (Eigenmann \& Allen, 1942)

Eigenmannia limbata (Schreiner \& Miranda Ribeiro, 1903)

Eigenmannia macrops (Boulenger, 1897)

Eigenmannia gr. trilineata López \& Castello, 1966
IDSM1001; IDSM59; IDSM637; IDSM746; IDSM754; IDSM758; IDSM2047; IDSM002056; IDSM002057; IDSM002095; IDSM002129; IDSM002147; IDSM002173; IDSM001869; INPA-ICT018315; INPA-ICT018314; INPAICT018313; INPA-ICT018312; INPA-ICT 018310; INPA-ICT018309; INPA-ICT018308; INPA-ICT018307; INPA-ICT018305; INPA-ICT018302; INPA-ICT018258; INPA-ICT018257; INPA-ICT015807; INPA-ICT9969; MCP33437; MCP33438; MCP33439; MCP33440; МCP33441; MCP33442

IDSM1986; IDSM2183; INPA-ICT15828; MCP41660 MCP37360*

IDSM1006; INPA-ICT15804; MCP37523; MCP37524; MCP37525; MCP37526; MCP37527; MCP37529; MCP37530; MCP37531

IDSM2291

MCP49414; MCP49415; MCP49416; MCP49417; MCP49418; MCP49419; MCP49420; MCP49421; MCP49422*

INPA-ICT15818

IDSM60; INPA-ICT15819; MCP33291; MCP33292

MCP49422**; MCP49423*

IDSM2177; IDSM2634; IDSM1873; IDSM2132; IDSM295; IDSM1050; IDSM1797; IDSM2148; IDSM2298; IDSM1942; INPA-ICT18264; INPAICT18263; INPA-ICT 18262; INPA-ICT18261; INPA-ICT18260; INPAICT18191; INPA-ICT15801; INPA-ICT09979; MCP33371; MCP33372; MCP33373; MCP33389; MCP49424; MCP49425; MCP49426; MCP49427; MCP49428; MCP49429; MCP49430; MCP49431; ZUEC-PIS12339

IDSM275; INPA-ICT18150; ZUEC-PIS12340; MCP33370; MCP49432; MCP49433; MCP49434; MCP49435; MCP49436

ZUEC-PIS12337*; ZUEC-PIS12338*

IDSM2176; IDSM2632; IDSM2146; IDSM2131; IDSM1800; IDSM1761; IDSM996; IDSM278; INPA-ICT18297; INPA-ICT18178; INPA-ICT18177; INPA-ICT15799; INPA-ICT11522; MCP38306

MCP37532; MCP37533; MCP37534; MCP37535; MCP37536; MCP37537; MCP37539; MCP37540; MCP37541; MCP37542

MCP33311; MCP37543

IDSM290; INPA-ICT18259; INPA-ICT15823; MCP33461; MCP33462; MCP33463; MCP33464; MCP33465; MCP33466; MCP41652; MCP41653; MCP41655; MCP41656; MCP41657; MCP41658

$$
\begin{aligned}
& \text { MCP41637*; MCP41638* } \\
& \text { IDSM2130 }
\end{aligned}
$$

MCP33285; MCP41640; MCP41641; MCP41642

IDSM1879; INPA-ICT18274; INPA-ICT18194; MCP33382; MCP33383; MCP33384; MCP33391

MCP41639; MCP41643; MCP41645; MCP41646; MCP41647; MCP41648; MCP41649; MCP41650; MCP41651

INPA-ICT15806*; INPA-ICT18164*; MCP37548*; MCP37549*; MCP37550*; MCP37554*; MCP37555*; MCP37556*; MCP37557*

IDSM1876; IDSM2190; IDSM2150; IDSM2172; IDSM995; INPA-ICT18301; INPA-ICT18300 INPA-ICT18299; INPA-ICT18031; INPA-ICT15812; INPAICT11517; MCP33286; MCP33287; MCP33288; MCP33289; MCP33290

IDSM98; IDSM128; IDSM732; IDSM778; IDSM779; IDSM1111; IDSM2051; IDSM2052; IDSM2097;INPA-ICT18684; INPA-ICT18683; INPA-ICT18681; INPA-ICT18288; INPA-ICT18287; INPA-ICT18286; INPA-ICT18285; INPAICT18282; INPA-ICT18281; INPA-ICT18202; INPA-ICT9976

IDSM96; IDSM1052; IDSM1870; IDSM2090; IDSM2098; IDSM2179; IDSM288 INPA-ICT15795 
...continuation

Eigenmannia virescens (Valenciennes, 1842)

Eigenmannia sp.1

Rhabdolichops caviceps (Fernández-Yépez, 1968)

Rhabdolichops eastwardi Lundberg \& Mago-Leccia, 1986

Rhabdolichops electrogrammus Lundberg \& Mago-Leccia, 1986

Rhabdolichops lundbergi Correa, Crampton \& Albert, 2006

Rhabdolichops navalha Correa, Crampton \& Albert, 2006

Rhabdolichops nigrimans Correa, Crampton \& Albert, 2006

Rhabdolichops troscheli (Kaup, 1856)

Sternopygus branco Crampton, Hulen \& Albert, 2004

Sternopygus macrurus (Bloch \& Schneider, 1801)
IDSM404; IDSM407; IDSM780; IDSM781; IDSM786; IDSM787; IDSM859; IDSM860; IDSM861; IDSM1005; IDSM1874; IDSM1848; IDSM2060; INPAICT35171; MCP33293; MCP33294; MCP33295; MCP33296; МCP33297

\section{MCP47752}

IDSM274; INPA-ICT15791; INPA-ICT9981; MCP35999; MCP36000; MCP36001; MCP36002; MCP36004; MCP36005; MCP36006; МCP36007; MCP36008; MCP36010; MCP36011; MCP36022

IDSM2180; IDSM273; INPA-ICT18220; INPA-ICT18218; INPA-ICT18217; INPA-ICT18212; INPA-ICT018211; INPA-ICT011518; MCP36012: MCP36013; MCP36014; MCP36015; MCP36018; MCP36019; MCP36020; MCP36023; МCP36024; МCP36025

МCP36027; МCP36028; МCP36029

IDSM1010; INPA-ICT18226; INPA-ICT18222; INPA-ICT25254*; MCP36031*; MCP36032*; MCP36033*; MCP36034*; MCP36035*; MCP36036*; MCP36037**; MCP36038*; MCP36039*; MCP36040*; MCP36042*; MCP36043*; MCP36044*; MCP36051

IDSM2094; IDSM2149; IDSM2182; IDSM1116; IDSM1872; IDSM1816

IDSM294; IDSM1007; IDSM1850; IDSM1871; IDSM1943; INPA-ICT18371; INPA-ICT18370; INPA-ICT18369; INPA-ICT18239; INPA-ICT18225; INPAICT18224; INPA-ICT18223; INPA-ICT18221; INPA-ICT15794

INPA-ICT18162; INPA-ICT9973; MCP36055; MCP36057; MCP36058

INPA-ICT18166; INPA-ICT15786*; MCP32241*; MCP32242*; MCP32243*; MCP32244*; MCP32245*; MCP32246*; MCP32451**

IDSM728; IDSM755; IDSM757; IDSM769; IDSM771; IDSM181; IDSM849; IDSM1011; IDSM1763; IDSM1976; IDSM2035; IDSM2036; IDSM2037; IDSM2038; IDSM2039; IDSM2040; IDSM2041; IDSM2042; IDSM2043; IDSM2044; IDSM2045; IDSM2053; IDSM2054; IDSM2055; IDSM2109; IDSM2128; INPA-ICT18316; INPA-ICT18190; INPA-ICT15802; INPAICT9974; MCP032247; MCP32248; MCP32250; MCP32251; MCP32252; MCP32258; MCP33374; MCP33375

GYMNOTIFORMES: Gymnotidae

Electrophorus varii de Santana, Wosiacki, Crampton, Sabaj, Dillman, Mendes-Júnior \& Castro e Castro, 2019

Gymnotus arapaima Albert \& Crampton, 2001

Gymnotus carapo Linnaeus, 1758

Gymnotus jonasi Albert \& Crampton, 2001

Gymnotus mamiraua Albert \& Crampton, 2001 MCP33436; MCP49987*; MZUSP75166.0 MZUSP75167.0; MZUSP75179.0
IDSM143; IDSM2667; IDSM2670; INPA-ICT57626; INPA-ICT15820

IDSM142; IDSM800; IDSM765; IDSM773; IDSM804; IDSM805; IDSM806; IDSM808; IDSM2046; IDSM2048; IDSM2049; IDSM2050; INPA-ICT18391;

INPA-ICT18390; INPA-ICT18389; INPA-ICT15833*; INPA-ICT14532*; INPA-ICT9963*; MCP33298; MCP33365; MCP33434; MCP33435; IDSM1788; IDSM734; IDSM801; IDSM1008; IDSM1978; IDSM809 IDSM122; IDSM217; IDSM802; IDSM810; IDSM811; INPA-ICT18318; INPA-ICT 11513; INPA-ICT15830*; MCP33331; MCP33332; MCP33334; MCP33335; MCP33336; MCP33337; MCP33338; МCP033339; MCP33340; MCP33341; MCP33342; MCP33343; МCP33366; МCP46931

IDSM191; IDSM218; IDSM219; IDSM733; IDSM764; IDSM766; IDSM767; IDSM772; IDSM803; IDSM807; IDSM812; IDSM869; IDSM870; IDSM871; IDSM872; IDSM873; IDSM874; IDSM1009; IDSM1861; IDSM1982; IDSM2114; IDSM2651; IDSM2665; IDSM2666; INPA-ICT18421; INPA-ICT18420; INPAICT18419; INPA-ICT18418; INPA-ICT18417; INPA-ICT18416; INPA-ICT18415; INPA-ICT18414; INPA-ICT18413; INPA-ICT18412; INPA-ICT18411; INPAICT18410; INPA-ICT18409; INPA-ICT18408; INPA-ICT18407; INPA-ICT18406; INPA-ICT18405; INPA-ICT18404; INPA-ICT18403; INPA-ICT18402; INPA-ICT 18401; INPA-ICT18400; INPA-ICT18399; INPA-ICT18398; INPA-ICT18397; INPA-ICT18396; INPA-ICT18395; INPA-ICT18394; INPA-ICT18393; INPAICT18392; INPA-ICT27577; INPA-ICT18159; INPA-ICT14537; INPA-ICT13504; INPA-ICT15832*; INPA-ICT9962*; INPA-ICT13503**; MCP29805; MCP33282; MCP33283; MCP33284; MCP33348; MCP33349; MCP33350; MCP33351; MCP33352; МCP33353; МCP33354 
HERCOS, A.P., et al.

...continuation

Gymnotus melanopleura Albert \& Crampton, 2001

Gymnotus obscurus Crampton, Thorsen \& Albert,2005

Gymnotus onca Albert \& Crampton, 2001

Gymnotus varzea Crampton, Thorsen \& Albert, 2005
INPA-ICT9966*

IDSM2636; MZUSP60604.0; MZUSP60605.0; MZUSP60606.0 INPA-ICT11512**

IDSM000797; IDSM798; IDSM281; INPA-ICT18424*; INPA-ICT18423*; INPA-ICT018422*; MZUSP60601.0; MZUSP60602.0; MZUSP60603.0; MZUSP75158.0*; MZUSP75159.0*; MZUSP75160.0*; MZUSP75161.0*; MZUSP75162.0*; MZUSP75163.0*; MZUSP75164.0*

\section{GYMNOTIFORMES: Hypopomidae}

Brachyhypopomus batesi Crampton, de, Santana, Waddell \& Lovejoy, 2016

Brachyhypopomus beebei (Schultz, 1944)

Brachyhypopomus belindae Crampton, de, Santana, Waddell \& Lovejoy, 2016

Brachyhypopomus bennetti Sullivan, Zuanon, Cox \& Fernandes, 2013

Brachyhypopomus brevirostris (Steindachner, 1868)

Brachyhypopomus flavipomus Crampton, de, Santana, Waddell \& Lovejoy, 2016

Brachyhypopomus hendersoni Crampton, de, Santana, Waddell \& Lovejoy, 2016

Brachyhypopomus hamiltoni Crampton, de, Santana, Waddell \& Lovejoy, 2016

Brachyhypopomus pinnicaudatus (Hopkins, Comfort, Bastian \& Bass, 1990)

\section{IDSM2065}

IDSM120; IDSM739; IDSM814; IDSM816; IDSM863; IDSM864; IDSM2074; IDSM2083; IDSM2091; INPA-ICT18341; INPA-ICT18338; INPA-ICT18337; INPA-ICT18336; INPA-ICT18335; INPA-ICT9943; MCP45313; MCP45342; MCP45343; MCP45344; MCP45358; MCP45361; MCP45380; MCP45381; MCP45382; MCP45383; MCP45385; MCP45387; MCP45420; MCP45421; MCP45422; MCP45424; MCP45427; MCP45428; MCP45450

$$
\text { MCP45267*; MCP45430*; MCP45431*; MCP47867*; MCP45360** }
$$

IDSM174; IDSM220; IDSM729; IDSM730; IDSM736; IDSM741; IDSM742; IDSM748; IDSM749; IDSM1987; IDSM1988; IDSM1989; IDSM1990; IDSM1991; IDSM1992; IDSM1993; IDSM1994; IDSM1995; IDSM1996; IDSM1997; IDSM1998; IDSM1999; IDSM2000; IDSM2001; IDSM2002; IDSM2003; IDSM2004; IDSM2005; IDSM2006; IDSM2007; IDSM2008; IDSM2009; IDSM2010; IDSM2011; IDSM2012; IDSM2013; IDSM2014; IDSM2015; IDSM2016; IDSM2017; IDSM2018; IDSM2019; IDSM820;

IDSM821; IDSM788; IDSM789; IDSM830; IDSM825; IDSM827; IDSM2025; IDSM2026; IDSM2027; IDSM2028; IDSM2029; IDSM2030; IDSM2064; IDSM2022; IDSM2089; IDSM836; IDSM837; IDSM840; IDSM866; IDSM867; IDSM868; IDSM843; IDSM1128; IDSM1766; IDSM2069; IDSM2072; IDSM2073; IDSM1863; IDSM2077; MCP33278; MCP33280; MCP33281; MCP45251; MCP45252; MCP45253; MCP45254; MCP45255; MCP45256; MCP45257; MCP45315; MCP45316; MCP45330; MCP45345; MCP45346; MCP45347; MCP45348; MCP45359; MCP45384; MCP45388; MCP45389; MCP45390; MCP45391; MCP45392; MCP45394; MCP45399; MCP45400; MCP45401; MCP45429; MCP45451; MCP45465; MCP46934; MCP47021; MZUSP75152.0*; MZUSP75153.0*; MZUSP75154.0*; MZUSP75155.0*; MZUSP75156.0*; MZUSP75157.0*

IDSM121; IDSM774; IDSM743; IDSM822; IDSM835; IDSM845; IDSM1110; IDSM1132; IDSM1928; IDSM1767; IDSM2600; IDSM1984; IDSM1886; IDSM2211; IDSM2108; INPA-ICT18252; INPA-ICT18251; INPA-ICT18250; INPA-ICT18249; INPA-ICT18248; INPA-ICT18247; INPA-ICT18343; INPAICT18342; MCP33367; MCP44758; MCP45259; MCP45260; MCP45261; MCP45262; MCP45317; MCP45318; MCP45319; MCP45323; MCP45326; MCP45331; MCP45362; MCP45363; MCP45386; MCP45395; MCP45396; MCP45402; MCP45403; MCP45404; MCP46927; MCP46930; MCP46935;

IDSM123; IDSM124; IDSM126; IDSM203; IDSM815; IDSM824; IDSM838; IDSM2020; IDSM2021; IDSM2062; IDSM2161; IDSM2079; IDSM2080; IDSM2084; IDSM2085; IDSM2646; MCP45264; MCP45265*; MCP45266*; MCP45329; MCP45349*; MCP45350*; MCP45364; MCP45365; MCP45367*; MCP45368; MCP45405*; MCP45406*; MCP45425*; MCP45453

\section{IDSM844}

\section{MCP45268; MCP45269*; MCP45482**}

IDSM731; IDSM737; IDSM738; IDSM792; IDSM175; IDSM215; IDSM248; IDSM464; IDSM817; IDSM826; IDSM829; IDSM832; IDSM839; IDSM853; IDSM2063; IDSM1129; IDSM1977; MCP45275; MCP45276; MCP45277; MCP45278; MCP45279; MCP45280; MCP45281; MCP45328; MCP45351; MCP45370; MCP45398; MCP45409; MCP45410; MCP45433; MCP45435; MCP45436; MCP45437; MCP45438; MCP45455; MCP46928 
...continuation

Brachyhypopomus walteri Sullivan, Zuanon, Cox \& Fernandes, 2013

Brachyhypopomus regani Crampton, de, Santana, Waddell \& Lovejoy, 2016

Brachyhypopomus sp. $\mathrm{n}$.

GYMNOTIFORMES: Rhamphichthyidae

Hypopygus lepturus Hoedeman, 1962

Steatogenys elegans (Steindachner, 1880)

Gymnorhamphichthys rondoni (Miranda Ribeiro, 1920)

Gymnorhamphichthys hypostomus Ellis, 1912

Rhamphichthys heleios Carvalho \& Albert, 2015

Rhamphichthys lineatus Castelnau, 1855

Rhamphichthys marmoratus Castelnau, 1855

Rhamphichthys rostratus (Linnaeus, 1766)

Rhamphichthys sp.1

SILURIFORMES: Trichomycteridae

Apomatoceros sp.1

Homodiaetus sp.1

Henonemus punctatus (Boulenger, 1887)

Megalocentor echthrus de Pinna \& Britski, 1991

Paravandellia sp. $n$.

Pareiodon microps Kner, 1855

Plectrochilus machadoi Miranda Ribeiro, 1917

Plectrochilus wieneri (Pellegrin, 1909)

Plectrochilus sp. $n$.

Pseudostegophilus nemurus (Günther, 1869)

Potamoglanis hasemani (Eigenmann, 1914)

Stegophilus septentrionalis Myers, 1927

Tridensimilis sp.1

Vandellia cirrhosa Valenciennes, 1846

Vandellia sanguinea Eigenmann, 1917

Vandellia sp.1

\section{SILURIFORMES: Callichthyidae}

Callichthys callichthys (Linnaeus, 1758)

Corydoras acutus Cope, 1872

Corydoras ambiacus Cope, 1872
IDSM221; IDSM833; IDSM834; IDSM1927; IDSM1881; IDSM1768; IDSM1140; IDSM2023; IDSM2024; IDSM2087; MCP33368; МCP33369; MCP44607; MCP44649*; MCP44742; MCP45290; MCP45291; MCP45292; MCP45293; MCP45295*; MCP45320*; MCP45321; MCP45327; MCP45412*; MCP45413; MCP45441; MCP45443; MCP45444*; MCP45445; MCP45458*; MCP45487; MCP45488*; MCP45490; MCP46933

IDSM740; IDSM2075; IDSM2288; IDSM2597; IDSM2598; IDSM2601;

IDSM2618; IDSM2192; IDSM2156; IDSM858; IDSM865; MCP45282; MCP45283; MCP45284; MCP45285; MCP45286; MCP45333*; MCP45334*;

MCP45335*; MCP45411*; MCP45439*; MCP45446*; MCP45456; MCP45473; MCP45484*; MCP47022**

MCP33279; MCP44744*; MCP44760; MCP45324*; MCP45459; MCP46021

\section{IDSM855}

IDSM761; IDSM253; IDSM793; IDSM993; IDSM1757; IDSM1794; IDSM1827; IDSM1880; IDSM2099; IDSM2115; INPA-ICT18231; INPAICT18171; INPA-ICT18169; INPA-ICT18168; INPA-ICT18167; INPAICT9957; MCP31923; MCP31929; MCP31930; MCP31931; MCP31936; MCP31937; MCP31938; MCP31939; MCP31941; MCP31942; MCP31943; MCP31944; MCP31945; MCP31948

In the process of cataloging

IDSM3031

INPA-ICT18332*; INPA-ICT18323*

INPA-ICT18276; MCP33456; MCP33457; MCP44757

IDSM542; IDSM735; IDSM750; IDSM794; IDSM1980; IDSM1985; IDSM2100; IDSM2178; MCP33380; MCP33381; MCP33450; MCP33452; MCP33454; MCP33455; MCP44604; MCP46929; MCP46932

IDSM1807; MCP33444; MCP33446

MCP33378; MCP47019
MCP33162; MCP33163; MCP33164; MCP33165

MCP29342

IDSM2138; IDSM2152; IDSM2181

IDSM2198; MCP29548; MCP30637; MCP30646;

MCP29562*

MCP29949; MCP29950

IDSM2153

IDSM2635

MCP29560*; MCP31629

IDSM132; IDSM2151; MCP30010; MCP30013; MCP30015

In the process of cataloging

MCP29554; MCP29557

In the process of cataloging

MCP30643

МCP30633

MCP29343; MCP29344; MCP29561 
HERCOS, A.P., et al.

...continuation

Corydoras elegans Steindachner, 1876

Corydoras latus Pearson, 1924

Corydoras leopardus Myers, 1933

Corydoras multiradiatus (Orcés V., 1960)

Corydoras pygmaeus Knaack, 1966

Corydoras splendens (Castelnau, 1855)

Corydoras gr. zygatus

Dianema longibarbis Cope, 1872

Hoplosternum littorale (Hancock, 1828)

Lepthoplosternum altamazonicum Reis, 1997

Lepthoplosternum pectorale (Boulenger, 1895)

Lepthoplosternum ucamara Reis \& Kaefer, 2005

Megalechis picta (Müller \& Troschel, 1849)

Megalechis thoracata (Valenciennes, 1840)
IDSM2603; IDSM2604; IDSM2123

IDSM2617

IDSM1777

In the process of cataloging

IDSM2605; IDSM2631

In the process of cataloging

In the process of cataloging

IDSM145; IDSM1979; IDSM2168; IDSM2650

IDSM147; IDSM286; IDSM1983; MCP29443; MCP29444; MCP29445; MCP29446; MCP29447; MCP29448; MCP29449; MCP29450; MCP29450; MCP29451; MCP29452; MCP29453; МCP29454; MCP29455; MCP29456; MCP29457

MCP29317; MCP29319; MCP29320; MCP29321; MCP29322; MCP29323; MCP29324; MCP29325; MCP29326; MCP29327; MCP29328; MCP34561; МCP34562

IDSM177; IDSM247; IDSM2674; IDSM2677; IDSM2678

MCP29316; MCP29318; MCP29329; MCP29582

IDSM185; IDSM1; IDSM1131; IDSM2110; IDSM2167

IDSM2675; IDSM2676; MCP32940; MCP32941; MCP32943; MCP32944; MCP32945; MCP32946

\section{SILURIFORMES: Loricariidae}

Acanthicus hystrix Spix \& Agassiz 1829

\section{IDSM2122}

Ancistrus dolichopterus Kner, 1854

Ancistrus hoplogenys (Günther, 1864)

Ancistrus sp.1 "mancha dorsal"

Ancistrus sp.2 "robusto"

Ancistrus sp.3

Aphanotorulus emarginatus (Valenciennes, 1840)

Aphanotorulus cf. emarginatus

Dekeyseria amazonica Rapp Py-Daniel, 1985

Dekeyseria scaphirhyncha (Kner, 1854)

Farlowella amazonum (Günther, 1864)

Farlowella gr. gracilis

Farlowella henriquei MirandaRibeiro, 1918

Farlowella nattereri Steindachner, 1910

Farlowella oxyrryncha (Kner, 1853)

Farlowella rugosa Boeseman, 1971

Hemiodontichthys acipenserinus (Kner, 1853)

Hypoptopoma bianale Aquino \& Schaefer, 2010

Hypoptopoma brevirostratum Aquino \& Schaefer, 2010
IDSM1030; IDSM1158; IDSM1745; IDSM1751; IDSM1752

MCP29784; IDSM1227

IDSM1170; IDSM1226; IDSM1244; IDSM1383; IDSM1384; IDSM1386; IDSM1167; IDSM1031; IDSM1159; IDSM1191; IDSM1197

IDSM1245

MCP29730; MCP29736

IDSM1023; IDSM1169; IDSM1229; IDSM1192; IDSM1318; IDSM1684; INPA-ICT19490; INPA-ICT19489; MCP30623; MCP30627; MCP33268; MCP33269; MCP33270; MCP33272; МCP33273

IDSM1317; IDSM1247; IDSM1180

IDSM1076; IDSM1258; IDSM1259; IDSM1260; IDSM1261; IDSM1262;

IDSM1263; IDSM1264; IDSM1265; IDSM1266; IDSM1267; IDSM1268; IDSM1269; IDSM1270; IDSM1271; INPA-ICT19496; INPA-ICT19495; INPAICT19494; MCP29765

INPA-ICT37654

MCP29738

IDSM1117

MCP29769

IDSM1153; IDSM1165; MCP29714; MCP29713; MCP29714; MCP29715; MCP29716; МCP29718

IDSM1026

IDSM1629

IDSM1670; IDSM1068; MCP29790; MCP29791; MCP29792; MCP29793; MCP29794

MCP29584; МCP29591; MCP33115

MCP29592 
Hypoptopoma gr. gulare Cope, 1878

Hypoptopoma psilogaster Fowler, 1915

Hypoptopoma thoracatum Günther, 1868

Hypostomus aff. plecostomus

Hypostomus carinatus (Steindachner, 1881)

Hypostomus cf. hoplonites

Hypostomus gr. pyrineusi

Limatulichthys griseus (Eigenmann, 1909)

Limatulichthys sp.1

Loricaria cataphracta Linnaeus, 1758

Loricaria simillima Regan, 1904

Loricaria sp.1

Loricariichthys acutus (Valenciennes, 1840)

Loricariichthys maculatus (Bloch, 1794)

Loricariichthys nudirostris (Kner, 1853)

Loricariichthys stuebelii (Steindachner, 1882)

Loricariichthys sp.1

Otocinclus vestitus Cope, 1872

Oxyropsis carinata (Steindachner, 1879)

Oxyropsis wrightiana Eigenmann \& Eigenmann, 1889

Peckoltia brevis (La Monte, 1935)

Peckoltichthys bachi (Boulenger, 1898)

Pseudorinelepis genibarbis (Valenciennes, 1840)

Pterosturisoma microps (Eigenmann \& Allen, 1942)

Pterygoplichthys gibbiceps (Kner, 1854)

Pterygoplichthys pardalis (Castelnau, 1855)

Rinelocaria cf. fallax

Rineloricaria castroi Isbrücker \& Nijssen, 1984
IDSM1027; IDSM1045; IDSM1160; IDSM1194; IDSM1195; IDSM1199; IDSM1202; IDSM1272; IDSM1273; IDSM1274; IDSM1275; IDSM1276; IDSM1277; IDSM1278; IDSM1279; IDSM1280; IDSM1281; IDSM1282; IDSM1283; IDSM1284; IDSM1285; IDSM1286; IDSM1287; IDSM1288; IDSM1289; IDSM1290; IDSM1291; IDSM1292; IDSM1293; IDSM1294; IDSM1295; IDSM1296; IDSM1297; IDSM1298; IDSM1299; IDSM1301; IDSM1302; IDSM1303; IDSM1304; IDSM1305; IDSM1724; IDSM1725; IDSM2680; IDSM2681; IDSM1234; INPA-ICT19065; INPA-ICT19064; INPAICT19062; MCP33106; MCP33107; MCP33108; MCP33109; MCP33112; MCP33113; МCP33114

IDSM1775

IDSM1204; IDSM1043; IDSM1155; IDSM1171; IDSM1237

IDSM402; IDSM1224; IDSM1243; IDSM2140

IDSM482; IDSM1161; IDSM1168; IDSM1230; IDSM1238; IDSM1310 IDSM118

IDSM1018; IDSM1142

INPA-ICT19090; INPA-ICT19089; IDSM1150

MCP29814; MCP29818

INPA-ICT19087; INPA-ICT19086; INPA-ICT19085

IDSM1357; IDSM1658

MCP30613; MCP31668; MCP31669; MCP31670; MCP31672; MCP31673; MCP31674

IDSM240; IDSM138; INPA-ICT18926; MCP29706; MCP29709

IDSM139; IDSM1074; IDSM1313; IDSM1355; IDSM1356; IDSM1358; IDSM1366; IDSM1369

IDSM1314; IDSM140; MCP29779; MCP29780; MCP29781

INPA-ICT18967; INPA-ICT18966

IDSM1315

IDSM1776

IDSM1149; IDSM1175; IDSM1183; IDSM1184; IDSM1185; IDSM1186; IDSM1188; IDSM1190; IDSM1196; IDSM1198; IDSM1200; IDSM1201; IDSM1203; IDSM1206; IDSM1209; IDSM1210; IDSM1211; IDSM1212; IDSM1300; IDSM1306; IDSM1307; IDSM1308; IDSM1309; IDSM1235; MCP29577

MCP29615; МCP30639

IDSM1024; IDSM1189; IDSM1225; IDSM1232; IDSM1236; IDSM2620

IDSM1025; IDSM2594; IDSM2621; IDSM1205; MCP33228

IDSM1371; IDSM1320; IDSM1321; IDSM1322; MCP29674; MCP29675; MCP29789; МCP30624

MCP33231

IDSM1223; IDSM1241; IDSM1319; IDSM1718; IDSM2682; IDSM1679 IDSM303; IDSM1375; IDSM1239; IDSM1240; IDSM1242; IDSM87; IDSM1022; IDSM1172; IDSM1179; IDSM239; IDSM1176; IDSM1207; IDSM1193; IDSM1219; IDSM1220; IDSM1221; IDSM1222; IDSM1228; IDSM1231; IDSM1252; IDSM1253; IDSM1254; IDSM1255; IDSM1256; IDSM1257; IDSM1380; IDSM1311; IDSM1312; IDSM1316; IDSM1719; IDSM1720; IDSM1721; IDSM1722; IDSM1723; INPA-ICT18862;

MCP31698; МCP31699; MCP31700; МCP31701; MCP31702

IDSM1029; IDSM1187; IDSM1337; IDSM1338; IDSM1328; IDSM1344; IDSM1345; IDSM1349; IDSM1350; IDSM1351; IDSM2207; IDSM1364; IDSM1561

IDSM717; INPA-ICT18674; INPA-ICT18673; MCP29749; MCP29823; MCP29822; MCP33249; MCP33250; MCP33251 
HERCOS, A.P., et al.

..continuation

Rineloricaria formosa Isbrücker \& Njissen, 1979

Rineloricaria cf. formosa

Rineloricaria hasemani Isbrücker \& Njissen, 1979

Rineloricaria lanceolata (Günther, 1868)

Rineloricaria phoxocephala (Eigenmann \& Eigenmann, 1889)

Rineloricaria $\mathrm{sp} .1$

Spatuloricaria sp.1

Sturisoma aff. brevirostre

\section{SILURIFORMES: Cetopsidae}

Cetopsis coecutiens (Lichtenstein, 1819)

Cetopsis sp.1

Cetopsis sp.2

\section{SILURIFORMES: Aspredinidae}

Bunocephalus aleuropsis Cope, 1870

Bunocephalus coracoideus (Cope, 1874)

Bunocephalus verrucosus (Walbaum, 1792)

Pterobunocephalus depressus (Haseman, 1911)

\section{SILURIFORMES: Auchenipteridae}

Ageneiosus intrusus Ribeiro, Rapp Py-Daniel \& Walsh, 2017

Ageneiosus inermis (Linnaeus, 1766)

Ageneiosus lineatus Ribeiro, Rapp Py-Daniel \& Walsh, 2017

Ageneiosus ucayalensis Castelnau, 1855

Ageneiosus uranophthalmus Ribeiro, Rapp \& Py-Daniel, 2010

Ageneiosus vittatus Steindachner, 1908

Auchenipterus ambyiacus Fowler, 1915

Auchenipterichthys coracoideus (Eigenmann \& Allen, 1942)

Auchenipterus nuchalis (Spix \& Agassiz, 1829)

Centromochlus existimatus Mees, 1974

Centromochlus heckelii (De Filippi, 1853)

Epapterus dispilurus Cope, 1878

Pseudepapterus hasemani (Steindachner, 1915)

Tatia intermedia (Steindachner, 1877)

Trachelyopterus galeatus (Linnaeus, 1766)

Trachelyopterus sp. "placa larga"

Trachycorystes porosus Eigenmann \& Eigenmann, 1888

Trachycorystes trachycorystes (Valenciennes, 1840)

Tympanopleura atronasus (Eigenmann \& Eigenmann, 1888)

Tympanopleura brevis Steindachner, 1881

Tympanopleura longipinna Walsh, Ribeiro, Rapp \& PyDaniel, 2015
IDSM262; IDSM264; IDSM1144; IDSM1325; IDSM1327; IDSM1330;

IDSM1331; IDSM1332; IDSM1334; IDSM1335; IDSM1336; IDSM1340; IDSM1341; IDSM1359; IDSM1360; IDSM2642; IDSM1778

$$
\begin{aligned}
& \text { In the process of cataloging } \\
& \text { In the process of cataloging } \\
& \text { IDSM1028; IDSM1348 }
\end{aligned}
$$

IDSM2647; IDSM2613; INPA-ICT18670; INPA-ICT18667; INPA-ICT18665; MCP29825; MCP29827; MCP33229; MCP29833

MCP29830

IDSM2690

IDSM1248; IDSM1086

IDSM298; MCP32816

MCP33235; МCP33253

MCP30622; МCP33252; МCP33254;

MCP29654

IDSM162; IDSM1067; IDSM1078; IDSM1875; IDSM2102; IDSM2117; IDSM2119; IDSM2679; MCP29643

IDSM1087; IDSM2637; IDSM2649

MCP29622; INPA-ICT18725; MCP29842; MCP29843

MCP32961; MCP32962; MCP32965

IDSM1058; IDSM186; IDSM718; IDSM292; IDSM1929; IDSM1811

MCP29895; МCP29897; MCP29899

IDSM293; IDSM2633; INPA-ICT18922; MCP29898; MCP32832; MCP32833; MCP32834; МCP32960; MCP32967

MCP32963

IDSM680; IDSM3

IDSM2206; MCP29402; MCP29403; MCP29404; MCP29406; MCP29407 IDSM2593; MCP29217; MCP29219; MCP29220; IDSM000157

MCP29882; MCP29884; MCP29885; МCP30602

IDSM134; INPA-ICT19031; INPA-ICT19029; MCP29838; MCP29839; MCP29840; MCP29841

IDSM38; IDSM2154; MCP29618; MCP29619

IDSM36; IDSM268; IDSM271; IDSM2157; MCP29331; MCP29332; MCP29333

MCP029606

IDSM2599

IDSM89; IDSM95; IDSM178; IDSM187; IDSM241; IDSM1771; IDSM1773; IDSM2579; MCP29412; MCP29354; MCP29412; MCP32804; MCP32805; MCP32809; MCP32809

IDSM1113; IDSM2576; IDSM2577

IDSM1002; IDSM1680; IDSM2210; IDSM2578

IDSM158

IDSM37; IDSM269; IDSM1041; IDSM1857; INPA-ICT18986; INPAICT18983; MCP33178; MCP33179

IDSM682; IDSM683; IDSM2586

MCP29602; MCP29603 
...continuation

Tympanopleura piperata (Eigenmann, 1912)

Tympanopleura rondoni (Miranda Ribeiro, 1914)

Tympanopleura $\mathrm{cf}$. brevis

Tympanopleura sp.1

SILURIFORMES: Doradidae

Acanthodoras cataphractus (Linnaeus, 1758)

Agamyxis pectinifrons (Cope, 1870)

Amblydoras affinis (Kner, 1855)

Anadoras grypus (Cope, 1872)

Anadoras weddellii (Castelnau, 1855, 1908)

Astrodoras asterifrons (Kner, 1853)

Centrodoras brachiatus (Cope, 1872)

Hassar cf. wilderi

Hemidoras morrisi Eigenmann, 1925

Hemidoras stenopeltis (Kner, 1855)

Leptodoras gr. Acipenserinus

Lithodoras dorsalis (Valenciennes, 1840)

Megalodoras uranoscopus (Eigenmann \& Eigenmann, 1888)

Nemadoras elongatus (Boulenger, 1898)

Nemadoras hemipeltis (Eigenmann, 1925)

Nemadoras humeralis (Kner, 1855)

Opsodoras boulengeri (Steindachner, 1915)

Opsodoras morei (Steindachner, 1881)

Opsodoras stuebelii (Steindachner, 1882)

Opsodoras sp.1

Ossancora asterophysa Birindelli, Sabaj \& Pérez, 2011

Ossancora fimbriata (Kner, 1855)

Ossancora punctata (Kner, 1855)

Oxydoras niger (Valenciennes, 1821)

Platydoras armatulus (Valenciennes, 1840)

Platydoras hancockii (Valenciennes, 1840)

Pterodoras granulosus (Valenciennes, 1821)

\section{IDSM1047; IDSM1814}

INPA-ICT18962; INPA-ICT18961; INPA-ICT18960; INPA-ICT18959; MCP29874; MCP29875; MCP29876; MCP29877

IDSM3034

MCP33177; MCP33180; MCP33183; MCP33184; MCP33185; MCP33186

IDSM3035; IDSM3036

IDSM129; IDSM1032; IDSM1960; IDSM1855; IDSM2093; MCP33150; MCP33151; MCP33152; MCP33153; INPA-ICT19104

IDSM1950; IDSM1959

IDSM1882; IDSM1926; IDSM1963; IDSM2664; IDSM1109; IDSM1770; INPA-ICT19581; INPA-ICT19579; INPA-ICT19578; INPA-ICT19577; INPAICT19576; INPA-ICT19569; INPA-ICT19568; MCP29526; MCP29527; MCP29529; MCP29530
IDSM3037
IDSM169
MCP29380
IDSM3039

IDSM131; IDSM296; IDSM015; IDSM2135; INPA-ICT19253; MCP29660; MCP32996; MCP32998; MCP33005

IDSM1016; IDSM1545; IDSM1841; IDSM1939; IDSM2155; IDSM2195; IDSM2197; INPA-ICT19371; INPA-ICT19365; MCP29887; MCP29891; MCP29892; MCP29893

IDSMI265

IDSM3040

IDSM172; IDSM107; IDSM1051; IDSM1901; IDSM1769; IDSM2295; MCP33195; МCP33197

IDSM2134; INPA-ICT19273; INPA-ICT19272; MCP33125; MCP33126; MCP41546

MCP33122; MCP33124

IDSM1055; INPA-ICT37004; INPA-ICT18889; INPA-ICT18886; INPA-

ICT18883; INPA-ICT18882; INPA-ICT18881; INPA-ICT18880; INPA-

ICT18878; INPA-ICT18877; MCP29531; MCP29532; MCP29534; MCP29535; MCP29536; МCP29538; MCP29539; МCP29541; MCP29542; MCP29646

IDSM1817

INPA-ICT19254; INPA-ICT19252

IDSM2160; IDSM1819; IDSM1981; INPA-ICT19251; INPA-ICT19250

MCP32997

MCP29644; MCP29645; MCP29668

MCP29786; МCP32956

IDSM173; IDSM1772; IDSM2187; IDSM1856; IDSM2648; INPA-ICT18737; MCP29662; MCP29663; МCP29665; MCP29666; MCP29667; MCP29806; MCP29807; МCP29808

IDSM88; IDSM266; MCP29463

IDSM170; IDSM2104; MCP33193

IDSM3041

IDSM94; IDSM267; IDSM2116; INPA-ICT19486; INPA-ICT19484;

INPA-ICT19480; INPA-ICT19478; INPA-ICT19477; INPA-ICT19476; INPA-ICT19475; INPA-ICT18735; MCP31686; MCP31687; MCP31688; MCP31691; MCP31692 
HERCOS, A.P., et al.

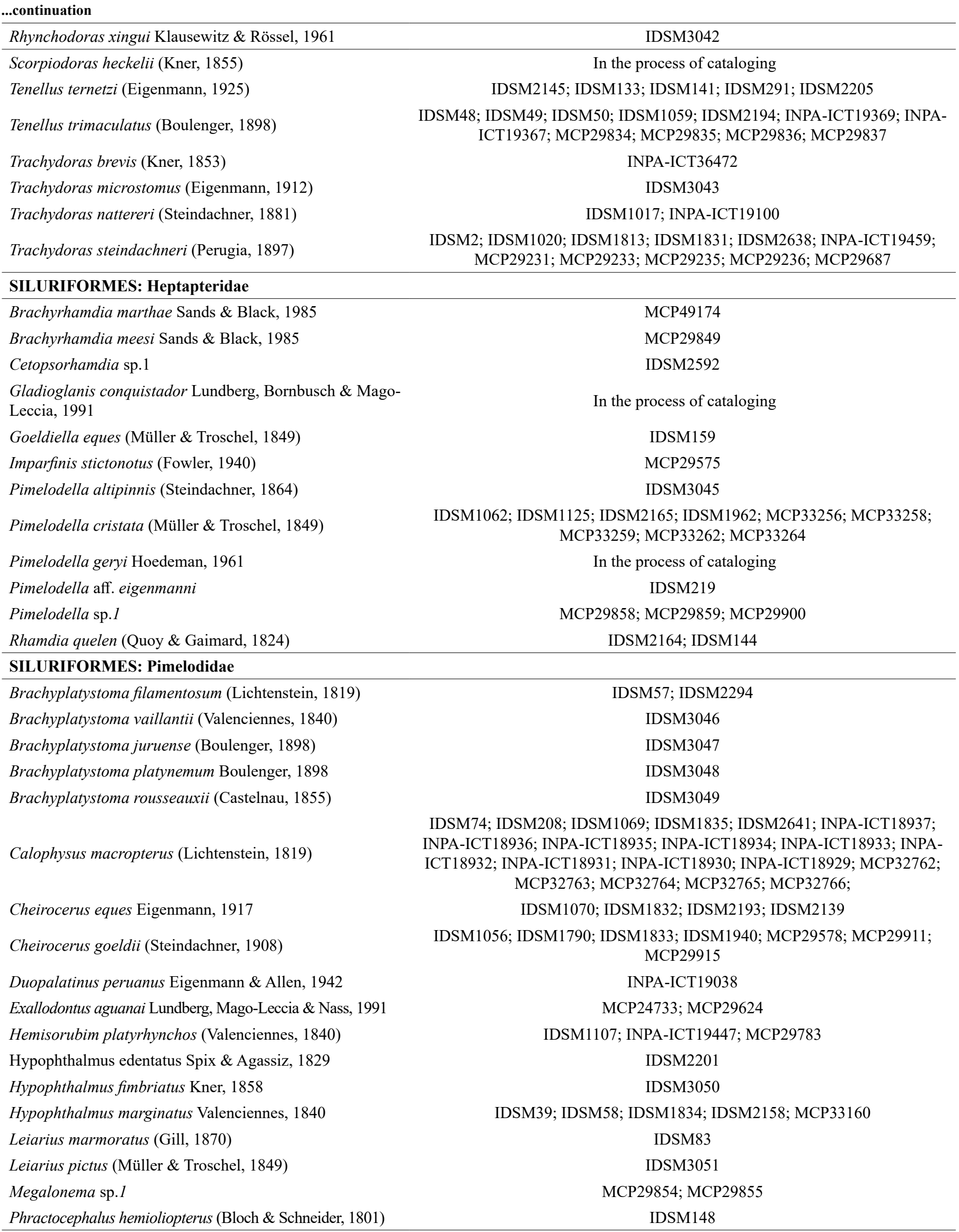


...continuation

Pimelodina flavipinnis Steindachner, 1876

Pimelodus albofasciatus Mees, 1974

Pimelodus altissimus Eigenmann \& Pearson, 1942

Pimelodus blochii Valenciennes, 1840

Pimelodus pictus Steindachner, 1876

Pimelodus ornatus Kner, 1858

Pinirampus pirinampu (Spix \& Agassiz, 1829)

Platysilurus mucosus (Vaillant, 1880)

Platynematichthys notatus (Jardine, 1841)

Platystomatichthys sturio (Kner, 1858)

Propimelodus caesius Parisi, Lundberg \& DoNascimiento, 2006

Propimelodus sp. 1

Pseudoplatystoma punctifer (Castelnau 1855)

Pseudoplatystoma tigrinum (Valenciennes, 1840)

Sorubim elongatus Littmann, Burr, Schmidt \& Isern, 2001

Sorubim lima (Bloch \& Schneider, 1801)

Sorubim maniradii Littmann, Burr \& Buitrago-Suarez, 2001

Sorubimichthys planiceps (Spix \& Agassiz, 1829)

Zungaro zungaro (Humboldt, 1821)

\section{SILURIFORMES: Pseudopimelodidae}

Batrochoglanis raninus (Valenciennes, 1840)

Batrochoglanis villosus (Eigenmann, 1912)

Microglanis poecilus Eigenmann, 1912

Microglanis sp. 1

Pseudopimelodus sp.1

SYNBRANCHIFORMES: Synbranchidae

Synbranchus lampreia Favorito, Zanata \& Assumpção, 2005

Synbranchus madeirae Rosen \&Rummey, 1972

Synbranchus sp.1

\section{CICHLIFORMES: Cichlidae}

Acarichthys heckelii (Müller \& Troschel, 1849)

Acaronia nassa (Heckel, 1840)

Aequidens tetramerus (Heckel, 1840)

Apistogramma agassizii (Steindachner, 1875)

Apistogramma bitaeniata Pellegrin, 1936

Apistogramma cacatuoides Hoedeman, 1951

Apistogramma eunotus Kullander, 1981

Apistogramma pertensis (Haseman, 1911)

Apistogramma regani Kullander, 1980
MCP30046; MCP30047; MCP30048; MCP30049; MCP30052 IDSM2163

IDSM297; MCP29869;

IDSM90; IDSM242; IDSM252; IDSM1000; MCP29222; MCP29223; MCP29224; MCP29458; MCP29460

MCP29853

In the process of cataloging

IDSM209; IDSM51; IDSM2191; IDSM1013; MCP32910; MCP32911; MCP32912; MCP32913; MCP32914

IDSM1019; IDSM1812; IDSM1821; IDSM2166; INPA-ICT19050; MCP29878; MCP29879; MCP29881

IDSM3053

IDSM1071; MCP31695

MCP29918; MCP29919; MCP29920

MCP29870

IDSM3054

IDSM161; IDSM1764; IDSM1952; MCP29886

IDSM1637; MCP30575

IDSM327; IDSM1021; INPA-ICT18855

INPA-ICT26636

IDSM3055

IDSM1941; IDSM2213; INPA-ICT19498
IDSM1112; IDSM2127; IDSM2169; INPA-ICT28580

IDSM1127; INPA-ICT18795

IDSM2292

IDSM180; MCP29625; MCP29626; MCP29627; MCP29629

MCP29845
MCP29363; MCP29364; MCP29365; МCP29366; МCP29367; МCP29368; MCP29369; MCP29370; MCP29371; MCP29372; МCP29373; МCP29374; MCP29375; MCP32915; МCP33025

IDSM1085; IDSM1862; IDSM1887; INPA-ICT18912; INPA-ICT18911; INPAICT 18868

IDSM189; IDSM1089; IDSM1779; IDSM1925; INPA-ICT18867; INPAICT18866; INPA-ICT18865; INPA-ICT18869; INPA-ICT52853; MCP33007; MCP33008; MCP33009; MCP33010; MCP33011; MCP33012; MCP33013; MCP33014; MCP33015; MCP33127; MCP33128; MCP33129 
HERCOS, A.P., et al.

...continuation

Apistogrammoides pucallpaensis Meinken, 1965

Astronotus ocellatus (Agassiz, 1831)

Biotodoma cupido (Heckel, 1840)

Bujurquina sp.1

Chaetobranchus flavescens Heckel, 1840

Chaetobranchus semifasciatus Steindachner, 1875

Cichla monoculus Spix \& Agassiz, 1831

Cichlasoma amazonarum Kullander, 1983

Crenicara punctulata (Günther, 1863)

Crenicichla cincta Regan, 1905

Crenicichla inpa Ploeg, 1991

Crenicichla lugubris Heckel, 1840

Crenicichla regani Ploeg, 1989

Crenicichla reticulata (Heckel, 1840)

Crenicichla proteus Cope, 1872

Crenicichla sp. 1

Geophagus proximus (Castelnau, 1855)

Geophagus cf. altifrons

Heros efasciatus Heckel, 1840

Hypselecara temporalis (Günther, 1862)

Laetacara thayeri (Steindachner, 1875)

Mesonauta insignis (Heckel, 1840)

Pterophyllum leopoldi (Gosse, 1963)

Pterophyllum scalare (Schultze, 1823)

Satanoperca acuticeps (Heckel, 1840)

Satanoperca jurupari (Heckel, 1840)

Satanoperca sp.1

Symphysodon tarzoo Lyons, 1959
IDSM202; IDSM2616

IDSM97; IDSM190; IDSM243; IDSM2668

IDSM3058

IDSM3014

IDSM216

IDSM249; MZUSP27926.0

IDSM201; IDSM246

IDSM84; IDSM244; IDSM245; IDSM199; IDSM795; IDSM1639; MCP33135; MCP33137; MCP33138

IDSM3013

MCP29338

INPA-ICT19388; MCP32986; MCP32987; MCP32988; MCP32989;

MCP32990; MCP32991; MCP33187; MCP331188; MCP33189; MCP33190; MCP33191; MCP33192

In the process of cataloging

MCP29608; MCP29611

IDSM40; IDSM2602; INPA-ICT19201; MCP33039; MCP33040

INPA-ICT18790; INPA-ICT18788

MCP38632

IDSM3060

In the process of cataloging

IDSM455; IDSM15; MCP32920; MZUSP27929.0

IDSM1894

IDSM101; IDSM2662; MCP29595; MCP29596; MCP29597; MCP29598

IDSM14

IDSM13; IDSM2141

IDSM2142

In the process of cataloging

MCP32818

MCP32819; MCP32820; IDSM3061

\section{CYPRINODONTIFORMES: Rivulidae}

Anablepsoides micropus (Steindachner, 1863)

Anablepsoides ornatus Garman, 1895

IDSM272; IDSM1916; IDSM2612; IDSM2628; IDSM2661;

IDSM1904

Anablepsoides sp.1

IDSM796*; INPA-ICT58224*; INPA-ICT58223**

CYPRINODONTIFORMES: Fluviphylacidae

Fluviphylax cf. pygmaeus

IDSM3062

BELONIFORMES: Belonidae

Potamorrhaphis guianensis (Jardine, 1843)

IDSM1958; INPA-ICT19000

Pseudotylosurus microps (Günther, 1866)

IDSM1098; IDSM1853; IDSM1923; MCP30038

TETRAODONTIFORMES: Tetradontidae

Colomesus asellus (Müller \& Troschel, 1849)

PERCIFORMES: Scianidae

Plagioscion montei Soares \& Casatti, 2000

Plagioscion squamosissimus (Heckel, 1840)

\section{GOBIIFORMES: Eleotridae}

Microphilypnus sp.1

IDSM1064; IDSM1662; MCP33033

\section{PLEURONECTIFORMES: Achiridae}

Hypoclinemus mentalis (Günther, 1862)

MCP30598; MCP32750

INPA-ICT19002; INPA-ICT19001; MCP31705

\section{CERATODONTIFORMES: Lepidosirenidae}

Lepidosiren paradoxa Fitzinger, 1837

IDSM1088; IDSM2113; IDSM2645; INPA-ICT18697; INPA-ICT18696; INPAICT18695; INPA-ICT18694 


\section{Conflicts of Interest}

The authors declare that there are no conflicts of interests related to the publication of this manuscript.

\section{References}

AFFONSO, A. G.; QUEIROZ, H. L.; NOVO, E. M. L. M. Limnological characterization of floodplain lakes in Mamirauá Sustainable Development Reserve, Central Amazon (Amazonas State, Brazil). Acta Limnologica Brasiliensia, v. 23, n. 1, p. 95-108, 2011. Doi: 10.4322/actalb.2011.023.

AFFONSO, A. G.; QUEIROZ, H. L.; NOVO, E. M. L. M. Abiotic variability among different aquatic systems of the central Amazon floodplain during drought and flood events. Brazilian Journal of Biology, v. 75, n. 4, p. 60-69, 2015.Doi: 10.1590/1519-6984.04214

ALBERT, J.; CRAMPTON, W. Five new species of Gymnotus (Teleostei: Gymnotiformes) from an Upper Amazonian floodplain, with descriptions of electric organ discharges and ecology. Ichthyological Exploration of Freshwaters, v. 12, p. 241-266, 2001.

ALBERT, J.; CRAMPTON, W. Pariosternarchus amazonensis: a new genus and species of Neotropical electric fish (Gymnotiformes: Apteronotidae) from the Amazon River. Ichthyological Exploration of Freshwaters, v. 17, n. 3, p. 267-274, 2006.

ALBERT J.; PETRY, P.; REIS, R. Major biogeographic and phylogeographic patterns. In: Historical biogeography of Neotropical Freshwater Fishes (ALBERT, J.S., REIS, R.E. eds.). University of California Press, Berkeley, p. 21-57, 2011. https://doi.org/10.1525/california/9780520268685.003.0002

ARANTES, C. C.; WINEMILLER, K. O.; PETRERE, M.; CASTELLO, L.; HESS, L. L. Relationship between forest cover and fish diversity in the Amazon River floodplain. Journal of Applied Ecology, v. 55, n. 1, p. 386395, 2017. Doi: 10.1111/1365-2664.12967.

ARTHINGTON, A. H.; DULVY, N. K.; GLADSTONE, W.; WINFIELD, I. J. Fish conservation in freshwater and marine realms: status, threats and management. Aquatic Conservation: Marine and Freshwater Ecosystems, v. 26, p. 838-857, 2016.

BELTRÃO, H. \& SOARES, M.Variação temporal na composição da ictiofauna do lago e igarapés da Reserva de Desenvolvimento Sustentável RDS-Tupé, Amazônia Central. Biota Amazônica, v. 8, n. 1, p. 34-42, 2018.

BELTRÃO H.; ZUANON, J.; FERREIRA, E. Checklist of the ichthyofauna of the Rio Negro basin in the Brazilian Amazon. Zookeys, v. 881, p. 53-89, 2019. https://doi.org/10.3897/zookeys.881.32055.

CARVALHO, L.; ZUANON, J.; SAZIMA, I. Natural History of Amazon Fishes.In: Tropical biology and conservation management: case studies. Encyclopedia of Life Support Systems (EOLSS) (DEL CLARO, K., OLIVEIRA, P.S., RICOGRAY, V. eds.) Publishers, Oxford, p. 113-144, 2009.

CARVALHO, T.; ALBERT, J. A new species of Rhamphichthys (Gymnotiformes: Rhamphichthyidae) from the amazona basin. Copeia, v. 103, n. 1, p. 34-41, 2015. https://doi:10.1643/CI-14-066.

CHAVES, R. Diversidade e densidade ictiofaunística em lagos de várzea da Reserva de Desenvolvimento Sustentável Mamirauá. Dissertação de mestrado, Universidade Federal do Pará, Belém, PA, 2006.

CORREA, S. B.; CRAMPTON, W. G. R.; ALBERT, J. Three New Species of the Neotropical Electric Fish Rhabdolichops (Gymnotiformes: Sternopygidae) from the Central Amazon, with a New Diagnosis of the Genus. Copeia, v. 1, p. 27-42, 2006. https://doi.org/10.1643/0045-8511(2006)006[0027:TNSOTN]2.0.CO;2.

CORREA, S. B.; CRAMPTON, W. G. R.; CHAPMAN, L. J.; ALBERT, J. S. A comparion of flooded forest and floating meadow fish assemblages in an upper Amazon floodplain. Journal of Fish Biology, v. 72, p. 629-644, 2008. doi: 10.1111/j.1095-8649.2007.01752.x.

CRAMPTON, W. G. R. Os peixes da Reserva Mamirauá: diversidade e história natural na planície alagável da Amazônia. In: Estratégias para Manejo de Recursos Pesqueiros em Mamirauá. (QUEIROZ H.L. \& CRAMPTON, W. eds.), Sociedade Civil Mamirauá/CNPq, Brasília, p. 10-36, 1999.

CRAMPTON, W. G. R.; HULEN, K.; ALBERT, J. Sternopygus branco:ANew Species of Neotropical Electric Fish (Gymnotiformes: Sternopygidae) from the Lowland Amazon Basin, with Descriptions of Osteology, Ecology, and Electric Organ Discharges. Copeia, v. 2, p. 245-259, 2004.https://doi.org/10.1643/CI-03-105R1
CRAMPTON, W. G. R.; DE SANTANA, C.; WADDELL, J.; LOVEJOY, N. A taxonomic revision of the Neotropical electric fish genus Brachyhypopomus (Ostariophysi: Gymnotiformes: Hypopomidae), with descriptions of 15 new species. Neotropical Ichthyology, v.14, n. 4, p. 639-790, 2016. https://doi. org/10.1590/1982-0224-20150146

CRAMPTON, W. G. R.; THORSEN, D.; ALBERT, J. Three New Species from a Diverse, Sympatric Assemblage of the Electric Fish Gymnotus (Gymnotiformes: Gymnotidae) in the Lowland Amazon Basin, with Notes on Ecology. Copeia, v. 1, p. 82-99, 2005. https://doi.org/10.1643/CI-03-242R2

DAGOSTAF.; DE PINNA M. Biogeography of Amazonian fishes: deconstructing river basins as biogeographic units. Neotropical Ichthyology, v. 15, n. 3, p. 1-24, 2017. https://doi.org/10.1590/1982-0224-20170034

DAGOSTA, F.; DE PINNA, M. The fishes of the Amazon: Distribution and biogeographical patterns, with a comprehensive list of species. Bulletin of the American Museum of Natural History, v. 431, p. 1-163, 2019. https:// doi.org/10.1206/0003-0090.431.1.1

DARWALL, W. R.; FREYHOF, J. Ö. R. G. Lost fishes, who is counting? The extent of the threat to freshwater fish biodiversity. Conservation of freshwater fishes, p. 1-36, 2016.

DE SANTANA, C.; CRAMPTON, W. G. R. Revision of the Deep-channel Electric Fish Genus Sternarchogiton (Gymnotiformes: Apteronotidae) Copeia, v. 2, p. 387-402, 2007. https://doi.org/10.1643/00458511(2007)7[387:ROTDEF]2.0.CO;2

DE SANTANA, C.; CRAMPTON, W. R. G. 2010.A Review of the South American Electric Fish Genus Porotergus (Gymnotiformes: Apteronotidae) with the Description of a New Species. Copeia, v. 2010, n. 1, p. 165-175, 2010. https://doi.org/10.1643/CI-05-136.

DE SANTANA, C.; VARI, R. 2010. Electric fishes of the genus Sternarchorhynchus (Teleostei, Ostariophysi, Gymnotiformes); phylogenetic and revisionary studies. Zoological Journal da Linnean Society, v. 159, p. 223-371, 2010. https://doi.org/10.1111/j.1096-3642.2009.00588.x

EVANS, K.; CRAMPTON, W. G. R.; ALBERT, J. Taxonomic revision of the deep channel electric fish genus Sternarchella (Teleostei: Gymnotiformes: Apteronotidae), with descriptions of two new species. Neotropical Ichthyology, v. 15, n. 2, e160168, 2017. https://doi.org/10.1590/1982-0224-20160168

FILHO, J. Grandes expedições à Amazônia brasileira 1500-1930. Metalivros, São Paulo, p. 241, 2009.

FREITAS, C. E. C.; SIQUEIRA-SOUZA, F. K.; FLORENTINO, A. C.; HURD, L. E. The importance of spacial scales to analysis of fish diversity in Amazonian floodplain lakes and implications for conservation. Ecology of Freshwater Fish, v. 23, p. 470-477, 2014.

GASTON, K.; HE, F.; MAGURAN, A.; MCGILL, B. Species occurrence and occupancy. In: Biological diversity: frontiers in measurement and assessment (MAGURRAN, A.E. \& MC GILL, B.J. eds). Oxford University Press, Oxford. p. 141-151, 2011.

GOULDING, M.; SMITH, N. J. H.; MAHAR, D. J. Floods of Fortune - Ecology and economy along the Amazon. New York: Columbia University Press, p. 193, 1996.

HENDERSON, P. A. 1999. O Ambiente Aquático da Reserva Mamirauá. In: Estratégias Para Manejo de Recursos Pesqueiros em Mamirauá (Queiroz, H.L. \& Crampton, W.G.R. eds). SCM, MCT/CNPq, Brasília, p. 208, 1999.

HENDERSON, P.; CRAMPTON, W. G. R. A comparison of fish diversity and abundance between nutrient-rich and nutrient-poor lakes in the Upper Amazon. Journal of Tropical Ecology, v. 13 n. 2, p. 175-198, 1997. https:// doi:10.1017/S0266467400010403

HENDERSON, P.; HAMILTON, H. Standing crop and distribution of fish in drifting and attached floating meadow within an Upper Amazonian varzea lake. Journal of Fish Biology, v. 47, n. 2, p. 266-276, 1995. https:// doi:10.1111/j.1095-8649.1995.tb01894.x

IBAMA. Livro Vermelho da Fauna Ameaçada de Extinção: V. VI- Peixes. ICMBio/MMA, Brasília, p. 1232, 2018.

JUNK, W. J.; BAYLEY, P. B.; SPARKS, R. E. The flood pulse concept in riverfloodplain systems. Canadian special publication of fisheries and aquatic sciences, v. 106, n. 1, p. 110-127, 1989.

JUNK, W. J.; SOARES, M. G. M.; BAYLEY, P. B. Freshwater fishes of the Amazon River basin: their biodiversity, fisheries, and habitats. Aquatic Ecosystem Health \& Management, v. 10, n. 2, p. 153-173, 2007. 
JUNK, W. J.; PIEDADE, M. T. F.; SCHÖNGART, J.; COHN-HAFT, M.; ADENEY, J. M.; WITTMANN, F. A classification of major naturallyoccurring Amazonian Lowland wetlands. Wetlands, v. 31, p. 623-640, 2011. doi:10.1007/s13157-011-0190-7

JUNK, W. J.; PIEDADE, M. T. F.; LOURIVAL, R.; WITTMANN, F.; KANDUS, P.; LACERDA, L. D.; BOZELLI, R. L.; ESTEVES, F. A.; NUNES DA CUNHA, K.; MALTCHIK, L.; SCHÖNGART, J.; SCHAEFFER-NOVELLI, Y.; AGOSTINHO, A. A. 2014. Brazilian wetlands: their definition, delineation, and classification for research, sustainable management, and protection. Aquatic Conservation: Marine and Freshwater Ecosystems, v. 24, p.5-22, doi:10.1002/aqc. 2386

KULLANDER, S., SILFVERGRIP, A. 1991. Review of the South American cichlid genus Mesonauta Günther (Teleostei, Cichlidae) with descriptions of two new species. Revue Suisse de Zoologie, v. 98, p. 407-448, 1991.

LUNDBERG, J. G. The temporal context for diversification of Neotropical fishes. In: Phylogeny and classification of Neotropical fishes (MALABARBA, L, REIS, R., VARI, R., LUCENA, C., LUCENA. eds.). EDIPUCRS, Porto Alegre, p. 67-91, 1998.

LUNDBERG, J.; COX-FERNANDES, C.; CAMPOS, R.; SULLIVAN, J. Sternarchella calhamazon n. sp., the amazon's most abundant species of apteronotid eletric fish, with a note on the taxonomic status of Sternarchus capanemae Steindachner, 1868 (Gymnotiformes, Apteronotidae). Proceedings of the Academy of Natural Sciences of Philadelphia, v. 162, n. 1, p. 157-173, 2013. https://doi.org/10.1635/053.162.0110.

MALABARBA, L. R.; REIS, R. E.; VARI, R. P.; LUCENA, Z. M.; LUCENA, C. A. (Eds). Phylogeny and Classification of Neotropical Fishes. Porto Alegre, Edipucrs, p. 603, 1998.

OBERDORFF, T.; DIAS. M.; JÉZEQUEL, C.; ALBERT, J.; ARANTES, C.; BIGORNE, R.; CARVARJAL-VELLEROS, F.; DE WEVER, A.; FREDERICO, R.; HIDALGO, M.; HUGUENY, B.; LEPRIEUR, F.; MALDONADO, M.; MALDONADO-OCAMPO, J.; MARTENS, K.; ORTEGA, H.; SARMIENTO, J.; TEDESCO, P.; TORRENTE-VILARA, G.; WINEMILLER, K.; ZUANON, J. Unexpected fish diversity gradients in the Amazon basin. Science advances, v. 5, n. 9, eaav8681, 2019. https:// doi.org/10.1126/sciadv.aav8681

OLIVEIRA, J. C.; OLIVEIRA, J. A.; ROSSATO, D. P. C. First record of Apistogrammoides pucallpaensis Meinken, 1965 (Perciformes, Cichlidae) for Brazil, in addition to fecundity information. Acta Limnologica Brasiliensia, Rio Claro, v. 31, n. 8, 2019. https://doi.org/10.1590/s2179$975 \times 4218$

OTA, R.; MESSAGE, H.; GRAÇA, W.; PAVANELLI, C. Neotropical Siluriformes as a Model for Insights on Determining Biodiversity of Animal Groups. PloS One, v. 10, n. 7, 2015. https://doi.org/10.1371/journal. pone.0132913.

PEDRO, J. P. B.; GOMES, M. C. R.; TRINDADE, M. E. J.; CAVALCANTE, D. P.; OLIVEIRA, J. A.; HERCOS, A. P.; ZUCCHI, N.; LIMA, C. B.; PEREIRA, S. A.; QUEIROZ, H. L. Influence of the hydrological cycle on physucal and chemical variables of water bodies in the várzea áreas of the Middle Solimões River region (Amazonas, Brazil). Uakari, v. 9, n. 2, p. 33 - 47, 2013 Doi: 10.31420/uakari.v9i2.149

PELÁEZ, O.; PAVANELLI, C. Environmental heterogeneity and dispersal limitation explain different aspects of $\beta$-diversity in Neotropical fish assemblages. Freshwater Biology, v. 64, n. 3, p. 497-505, 2018. https://doi. org/10.1111/fwb.13237

QUEIROZ, L.; TORRENTE-VILARA, G.; OHARA, W.; PIRES, T.; ZUANON, J.; DORIA, C. Peixes do rio Madeira, volumes 1, 2 e3. Santo Antônia Energia, São Paulo. 2013.

QUEIROZ, H. A RDSM-um modelo de área protegida de uso sustentável. Estudos Avançados. Dossiê Amazônia, v. 54, n. 2, p. 183-204, 2005. https:// doi.org/10.1590/S0103-40142005000200011

RAMALHO, E.; MACEDO, J.; VIEIRA, T.; VALSECCHI, J.; CALVIMONTES, J.; MARMONTEL, M.; QUEIROZ, H. Ciclo hidrológico nos ambientes de várzea da Reserva de Desenvolvimento Sustentável Mamirauá Médio Rio Solimões, Período de 1990 a 2008. Uakari, v. 5, n. 1, p. 61-87, 2009.

REIS, L. Estudo das comunidades de peixes em poças de inundação formadas na mata de várzea da Reserva de Desenvolvimento Sustentável Mamirauá, Amazonas, Brasil. Monografia de Conclusão do Cusro de Ciências Biológicas, Universidade Federal de Lavras, Lavras, MG. 2007.
SAINT-PAUL, U.; ZUANON, J.; VILLACORTA-CORREA, M.A.; GARCIA, M.; FABRÉ, N. N.; BERGER, U.; JUNK, W.J. Fish communities in central Amazonian white- and blackwater floodplains. Environmental Biology of Fishes, v. 57, p. 235-250, 2000.

SANTOS, G. M.; FERREIRA, E. J. G.; ZUANON, J. A. S. Ecologia de peixes da Amazônia. In: Bases científicas para estratégias de preservação e desenvolvimento da Amazônia: fatos e perspectivas (VAL, A.L.; FIGLUIOLO, R.; FELDBERG, E. Eds.). Manaus: INPA/UFAM, Imprensa Universitária, v. 1, p. 263-280, 1991.

SANTOS, M. Estudo da comunidade de peixes do capim flutuante do paraná do Apara, Reserva de Sustentável Mamirauá. Monografia de Conclusão do Cusro de Ciências Biológicas, Universidade Federal de Lavras, Lavras, MG. 2007.

SIQUEIRA-SOUZA, F. K.; FREITAS, C. E. C.; HURD, L. E.; PETRERA Jr, M. 2016. Amazon floodplain fish diversity at different scales: do time and place really matter? Hydrobiologia, v. 776, n. 1, p. 99-110, 2016. Doi: 10.1007/s10750-016-2738-2.

SLEEN, P., ALBERT J. S. Field Guide to the Fishes of the Amazon, Orinoco e Guianas. Princeton University Press, Princeton. 2018.

SNOEKS, J., HARRISON, I., STIASSNY, M. The status and distribution of freshwater fishes. In: The diversity of life in African freshwaters: underwater, under threat. An analysis of the status and distribution of freshwater species throughout mainland Africa. (DARWALL, W., SMITH, K., ALLEN, D., HOLLAND, R., HARRINSON, I., BROOKS, E. eds.). IUCN, Gland, Switzerland, p. 42-91, 2011.

SULLIVAN, J., ZUANON, J., COX-FERNANDES, C. Two new species and a new subgenus of toothes Brachyhypopomus eletric knifefishes (Gymnotiformes, Hypopomidae) from a the central Amazon and considerations pertaining to the evolution of a monophasic eletric organ discharge. Zookeys, v. 327, p. 1-34, 2013. https://doi.org/10.3897/ zookeys.327.5427.

TOLEDO-PIZA, M.; MATTOX, G.; BRITZ, R. Priocharax nanus, a new miniature characid from the rio Negro, Amazon basin (Ostariophysi: Characiformes), with an updated list of miniature Neotropical freshwater fishes. Neotropical Ichthyology, v. 12, n. 2, p. 229-246, 2014. https://doi. org/10.1590/1982-0224-20130171

VAL, A. L.; ALMEIDA-VAL, V.M.F. Fishes of the Amazon and Their Environments. Physiological and Biochemical Features. Heidelberg: Springer Verlag. 1995.

VALSECCHI, J.; MARMONTEL, M.; FRANCO, C.L.B.; CAVALCANTE, D.P.; COBRA, I.V.D.; LIMA, I.J.; LANNA, J.M.; FERREIRA, M.T.M.; NASSAR, P.M.; BOTERO-ARIAS, R.; MONTEIRO, V. Atualização e composição da lista - Novas Espécies de Vertebrados e Plantas na Amazônia 2014-2015. WWF e IDSM. Brasília, DF e Tefé, AM, p. 111, 2017.

VAN DER SLEEN, P.; ALBERT, J. Field Guide to the Fishes of the Amazon, Orinoco, and Guianas. Princeton University Press, Princeton. 2017.https:// doi.org/10.2307/j.ctt1qv5r0f

WEITZMAN, S.; VARI, R. Miniaturization in South American freshwater fishes; an overview and discussion. Proceedings of the Biological Society of Washington, v.101, n. 2, p. 444-465, 1988.

WITTMANN, F.; SCHONART, J.; MONTERO, J.; MOTZER, T.; JUNK, W.; PIEDAD, M.; QUEIROZ, H.; WORBES, M. Tree species composition and diversity gradients in white water forests across the Amazon Basin. Journal of Biogeography, v. 3, n. 8, p. 1334-1347, 2006. https://doi. org $/ 10.1111 / \mathrm{j} .1365-2699.2006 .01495 . \mathrm{x}$

ZUANON, J.; PY-DANIEL, L. H. R.; FERREIRA, E. J. G.; CLARO JR., L. H.; MENDONÇA, F. P. Padrões de distribuição da ictiofauna na várzea do Sistema Solimões-Amazonas entre Tabatinga (AM) e Santana (AP). In: Conservação da várzea: identificação e caracterização de regiões biogeográficas (ALBERNAZ, A.L.K.M. Org.).

Received: 18/02/2021

Revised: 01/09/2021

Accepted: 02/09/2021

Published online: 18/10/2021 